\title{
Effect of annealing on microstructure, residual stress, and hardness of Al-Ti multilayered films
}

\author{
R. Mitra \\ Defence Metallurgical Research Laboratory, Kanchanbagh, Hyderabad 500 058, India \\ A. Madan and R.A. Hoffman \\ Advanced Coating Technology Group, Northwestern University, Evanston, Illionois 60208 \\ W-A. Chiou and J.R. Weertman \\ Department of Materials Science and Engineering, Northwestern University, \\ Evanston, Illionois 60208
}

(Received 12 October 2000; accepted 23 April 2001)

\begin{abstract}
Al-Ti multilayered films (12 at.\% Ti) with bilayer period of $16 \mathrm{~nm}$ were deposited by magnetron sputtering. The films were annealed in vacuum at 350 or $400{ }^{\circ} \mathrm{C}$ between 2 and $24 \mathrm{~h}$. During annealing, a diffusion-controlled chemical reaction between $\mathrm{Al}$ and Ti layers led to $\mathrm{Al}_{3} \mathrm{Ti}$ precipitation. Differential thermal analysis studies showed an exothermic reaction associated with $\mathrm{Al}_{3} \mathrm{Ti}$ formation, taking place between 320 and $390{ }^{\circ} \mathrm{C}$, depending on the heating rate. The evolution of microstructure with annealing was examined with transmission electron microscopy and x-ray diffraction. The hardness and residual stress of the films in the as-deposited and annealed conditions were studied in relation to the microstructural changes on annealing.
\end{abstract}

\section{INTRODUCTION}

There has been a significant interest in the research and development of dispersion-hardened aluminum for many years because of its properties, such as high specific strength and stiffness. Such materials are usually processed by powder or ingot metallurgy routes. However, other nonconventional synthesis techniques, such as rapid solidification processing (RSP) and physical vapor deposition (PVD), have also been studied. In the vapor deposition process, the material is transformed from a solid source into atoms and then condensed to form a new solid. The desublimation rates are extremely high, $10^{12} \mathrm{~K} / \mathrm{s}$. This is higher than the cooling rates in RSP processes and provides extended solid solubility and highly refined grain structures. Vapor deposition can be carried out either by thermal or electron beam evaporation followed by condensation of nanophase particles in an inert gas or by evaporation or sputtering of elemental or alloy sources with subsequent deposition of the evaporated or sputtered atoms on suitable substrates. In the case of inert gas condensation, the nano-sized powders have to be collected and compacted, which can lead to heterogeneities in composition, ${ }^{1}$ and porosity and flaws of different kinds. ${ }^{2}$ On the other hand, the consolidation step is bypassed during deposition by sputtering of suitable targets, and the composition of the product is directly related to the sequence followed in the sputtering of the different targets. Sputtering is also a more feasible process when the alloy constituents possess widely differing vapor pressures, e.g., $\mathrm{Al}-\mathrm{Zr}$ and $\mathrm{Al}-\mathrm{Ti}$.

Bilayered or multilayered films and diffusion couples of Al-Ti and other Al-metal systems have been studied over two decades. ${ }^{3-21}$ Research has revealed that heating of the films leads to the formation of Al-rich intermetallic compounds, either as interfacial layered reaction products ${ }^{4-9}$ or as discontinuous and equiaxed phases. ${ }^{5,9,10,11}$ A process that leads to the formation of a fine discontinuous and equiaxed intermetallic phase in an Al matrix can be used to produce dispersion-hardened Al composites.

In the present investigation, Al-Ti multilayered films were prepared by direct current (dc) magnetron sputtering. These were subsequently annealed at 350 or $400{ }^{\circ} \mathrm{C}$ in vacuum for different intervals of time to induce interdiffusion between $\mathrm{Al}$ and $\mathrm{Ti}$ layers followed by chemical reaction to precipitate fine particles of $\mathrm{Al}_{3} \mathrm{Ti}$. The evolution of the microstructure as a result of different periods of annealing was carefully studied by transmission electron microscopy (TEM) of plan-view and cross-section specimens. The variations of hardness and residual stress with alterations in the microstructure resulting from annealing were investigated with the prospect of developing the process of sputtering and annealing to produce dispersion-hardened aluminum with attractive properties. A preliminary report of this study was published earlier in Ref. 21. 


\section{EXPERIMENTAL PROCEDURE}

\section{A. Processing}

Al-Ti multilayered films of $0.1-$ or $1.7-\mu \mathrm{m}$ thickness were prepared by magnetron sputtering with $\mathrm{Al}$ of $99.9 \%$ purity and $\mathrm{Ti}$ of $99.4 \%$ purity as targets and $\mathrm{Si}$ (100) or $\mathrm{NaCl}$ as substrates. The targets were supplied by TKC (Lockport, IL). The trace impurities in Al target were Cr (5 ppm), Mn (15 ppm), K (0.01 ppm), Si (60 ppm), Cu (25 ppm), and $\mathrm{Mg}$ (57 ppm), while those in the Ti target were $\mathrm{Al}(5 \mathrm{ppm}), \mathrm{Cr}(5 \mathrm{ppm}), \mathrm{Mo}(0.03 \mathrm{ppm}), \mathrm{K}$ (0.01 ppm), Si (1 ppm), Fe (85 ppm), Ca (0.1 ppm), V (2 ppm), Ni (18 ppm), Cu (0.03 ppm), Mg (0.01 ppm), $\mathrm{Pb}(<5 \mathrm{ppm}), \mathrm{Na}(<1 \mathrm{ppm}), \mathrm{Zn}(24 \mathrm{ppm})$, and $\mathrm{Li}$ $(0.005 \mathrm{ppm})$. Using a computer-controlled pallet, the substrates were alternately moved under the $\mathrm{Al}$ and $\mathrm{Ti}$ targets for deposition of the $\mathrm{Al}$ and $\mathrm{Ti}$ layers, respectively, without applying a substrate bias. The deposition was carried out at ambient temperature. The target powers and the pallet speed were adjusted to maintain the bilayer thickness at around $16 \mathrm{~nm}$ with $\mathrm{Ti}$ constituting $12 \%$ of the total thickness. The as-deposited films on $\mathrm{Si}$ and $\mathrm{NaCl}$ substrates were annealed at $350{ }^{\circ} \mathrm{C}\left(0.67 T_{\mathrm{m}}\right.$ of $\mathrm{Al})$ or $400{ }^{\circ} \mathrm{C}\left(0.72 T_{\mathrm{m}}\right.$ of $\left.\mathrm{Al}\right)$ in a vacuum furnace (with pressure of $1 \times 10^{-5}$ torr) for periods between 2 and $24 \mathrm{~h}$. The heating rate of the furnace was $3.6^{\circ} \mathrm{C} / \mathrm{min}$ for the $350{ }^{\circ} \mathrm{C}$ anneal and $4.1{ }^{\circ} \mathrm{C} / \mathrm{min}$ for the $400{ }^{\circ} \mathrm{C}$ heat treatment. Annealing of the films was aimed at inducing interdiffusion and chemical reaction between $\mathrm{Al}$ and $\mathrm{Ti}$ to form the intermetallic precipitates.

The thickness to which the Al-Ti films were grown was decided on the basis of the type of study to be performed using them. The films of $0.1-\mu \mathrm{m}$ or slightly less thickness were electron transparent and could be directly used as plan-view samples for transmission electron microscopy (TEM) studies. On the other hand, thicker films are required for hardness measurements using the nanoindenter to obtain reliable data, and films with thickness of $1.7 \mu \mathrm{m}$ were used.

\section{B. Characterization}

\section{Microstructure}

The as-deposited and annealed Al-Ti films on Si substrates were studied with $\mathrm{x}$-ray diffraction (XRD) to identify the phases. XRD scans were performed on a SCINTAG XDS2000 x-ray diffractometer (Applied Research Laboratories, S.A., Ecublens, Switzerland) using $\mathrm{Cu} \mathrm{K} \mathrm{K}_{\alpha 1}$ radiation (Wavelength $=1.54056 \AA$ ), between $20^{\circ}$ and $90^{\circ}$ for phase identification, and low-angle XRD was carried out on as-deposited films to identify the presence of layered structure.

Further microstructural investigations were carried out using conventional and high-resolution transmission electron microscopy (HRTEM) on plan-view and cross-section TEM specimens. As-deposited Al-Ti films of $0.1-\mu \mathrm{m}$ thickness on $\mathrm{NaCl}$ substrates were floated off by immersion in water, and small fragments were fished on to $\mathrm{Cu}$ grids of 3-mm diameter for plan-view TEM studies. In addition, plan-view TEM specimens of Al-Ti films (1.7- $\mu \mathrm{m}$ thickness) annealed at $350{ }^{\circ} \mathrm{C}$ for 2 and $12 \mathrm{~h}$ were prepared from films deposited on Si substrates by mechanical polishing and argon ion milling from the $\mathrm{Si}$ side. Cross-section TEM specimens were also prepared from 1.7- $\mu \mathrm{m}$ thick films grown on Si substrates by dimpling and ion milling. Argon ion milling was carried out on a Gatan Ion mill, model 600 (Gatan, Inc., Pleasanton, CA) with a liquid nitrogen cooled stage. Conventional TEM examination was performed on the as-deposited and variously annealed plan-view and cross-section specimens using a Hitachi H-8100 TEM (Hitachi Instruments Ltd., Tokyo, Japan) at an acceleration voltage of $200 \mathrm{kV}$. Sizes of $\mathrm{Al}$ grains and $\mathrm{Al}_{3} \mathrm{Ti}$ precipitates were measured from a study of bright- and dark-field TEM images of both plan-view and crosssection specimens. At least $200 \mathrm{Al}$ grains and $300 \mathrm{Al}_{3} \mathrm{Ti}$ particles from different areas of each specimen were measured. HRTEM studies were conducted on the crosssection specimens of an as-deposited $\mathrm{Al}-\mathrm{Ti}$ film on $\mathrm{Si}$ substrate and a few annealed specimens using a Hitachi, H-9000 HREM (Hitachi Instruments Ltd., Tokyo, Japan), operating at $300 \mathrm{kV}$ acceleration voltage and without the use of objective aperture.

\section{Differential thermal analysis}

The temperature and type of the chemical reaction between $\mathrm{Al}$ and $\mathrm{Ti}$ were studied by heating free-standing Al-Ti multilayered films (separated from the substrate) in an argon environment in the furnace of a Perkin Elmer (Perkin Elmer Instruments, Inc., Norwalk, CT) differential thermal analyzer (DTA). Heating rates were varied between 2 and $25^{\circ} \mathrm{C} /$ minute and the films were heated from room temperature to $500{ }^{\circ} \mathrm{C}$. For comparison, a free-standing pure $\mathrm{Al}$ film was also heated at $5{ }^{\circ} \mathrm{C} / \mathrm{min}$ under similar conditions in the DTA furnace.

\section{Stress measurement}

The Al-Ti film deposited on Si substrates was in a stressed state. Measurement of the stress was carried out by determination of the curvature of Si wafer beams $(82 \times 10 \times 0.528 \mathrm{~mm})$ before and after deposition of Al-Ti multilayers and after annealing for $2 \mathrm{~h}$ at 350 and $400{ }^{\circ} \mathrm{C}$, using a Sloan DEKTAK 3030ST high-resolution diamond stylus profilometer (Yeagle Technology, Inc., Ashford, CT). The Al-Ti film was 1.7- $\mu \mathrm{m}$ in thickness. The stress $\sigma$ in the film was calculated from Stoney's equation: ${ }^{22}$

$$
\sigma=B_{\mathrm{s}}\left[4 t_{\mathrm{s}}^{2} / 3 L^{2} t_{\mathrm{f}}\right] \delta
$$


where $B_{\mathrm{s}}$ is the biaxial modulus of the substrate and is given by $E_{\mathrm{s}} /\left(1-v_{\mathrm{s}}\right), E_{\mathrm{s}}$ and $v_{\mathrm{s}}$ being Young's modulus and Poisson's ratio of the substrate, respectively; $\delta$ is the deflection in the beam due to deposition or annealing and is the difference between the curvatures before and after deposition or after annealing. $L$ is the length scanned on the beam (50 $\mathrm{mm}$ in this study) whose curvature is measured, while $t_{\mathrm{s}}$ and $t_{\mathrm{f}}$ are thickness of the substrate and film, respectively.

\section{Hardness measurement}

Hardness measurements were carried out with a UMIS-2000 ultra-microindentation system (Australian Scientific Instruments Pty Ltd., Canberra, Australia) equipped with a Berkovich diamond indenter on the 1.7- $\mu \mathrm{m}$-thick, as-deposited and annealed Al-Ti multilayered films on Si substrates. A load of $4 \mathrm{mN}$ was used to measure hardness, and the depth of penetration of the indenter was less than $15 \%$ of the thickness of the film. The unloading curve was analyzed to determine the hardness. ${ }^{23}$ The hardness was obtained by averaging the results of $15-20$ tests.

\section{RESULTS AND DISCUSSION}

\section{A. Microstructure in as-deposited Al-Ti multilayered film}

Low-angle XRD and TEM studies showed that a well-defined layered structure was present in the asdeposited Al-Ti film. Energy dispersive spectroscopy (EDS) analyses of the Al-Ti multilayered film on $\mathrm{Si}$ substrate with SEM, as well as that of plan-view samples with the TEM showed only $\mathrm{Al}$ and Ti peaks and no impurity atom segregation. The trace impurities present in the target materials are expected to be also present in the as-deposited Al-Ti films. It is possible that the trace impurities, depending on their concentration, may have certain roles to play in film growth and phase transformations, which were studied here and need to be investigated separately.

Figures 1(a) and 1(b) show a bright- and dark-field TEM image of an Al-Ti multilayered film, respectively. The layered structure is well defined, though it looked wavy in many regions [Fig. 1(a)]. The dark-field TEM image in Fig. 1(b) was recorded by centering of the arrowed region of the $\{111\} \mathrm{Al} /\{0002\} \mathrm{Ti}$ diffraction rings [Fig. 1(c)] using beam tilt. The diffraction rings corresponding to $\{111\} \mathrm{Al}(d=0.2338 \mathrm{~nm})$ and $\{0002\} \mathrm{Ti}$ $(d=0.2342 \mathrm{~nm})$ coincide. Bright- and dark-field TEM images in Figs. 1(a) and 1(b) show columnar growth of $\mathrm{Al}$ grains interrupted by $\mathrm{Ti}$ layers, which is similar to the observations in previous studies. ${ }^{24,25}$ In the present investigation, "columnar growth" of $\mathrm{Al}$ refers to the fact that a set of $\mathrm{Al}$ grains between the $\mathrm{Ti}$ interlayers, aligned along a column [as shown in Figs. 1(a) and 1(b)], grow with the same $\{111\}$ orientation.

The dark-field image of Al/Ti interfaces in Fig. 1(b) also shows misfit strain contrast inside the Al layer at the interface at intervals of about 3-4 nm, implying misfit strain localization and semicoherency. Misfit strain at the interface also leads to the streaking of diffraction spots perpendicular to the interface [shown with arrows in Fig. 1(c)] on the $\{111\} \mathrm{Al}$ and $\{0002\} \mathrm{Ti}$ rings, which coincide.

XRD pattern [Fig. 2(a)] and electron diffraction (ED) pattern [using a much larger selected area aperture than in Fig. 1(c) to represent a large number of grains] from plan-view sample [Fig. 2(b)] of an as-deposited Al-Ti sample show strong evidence of $\{111\}$ fiber texture in Al-layers and $\{0002\}$ texture in Ti layers, with the electron beam parallel to the fiber axis, ${ }^{26,27}$ and similar texture has been reported in the literature of $\mathrm{Al}-\mathrm{Ti}$ multilayered films. ${ }^{24,25,28-30}$ In the XRD pattern [Fig. 2(a)], peaks other than $\{111\} \mathrm{Al}$ and $\{0002\} \mathrm{Ti}$

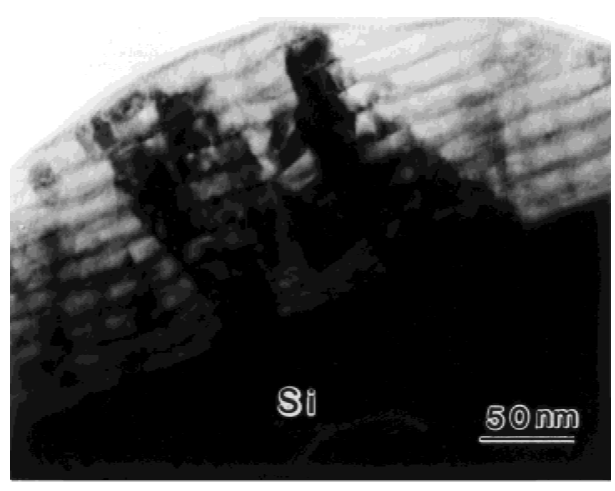

(a)

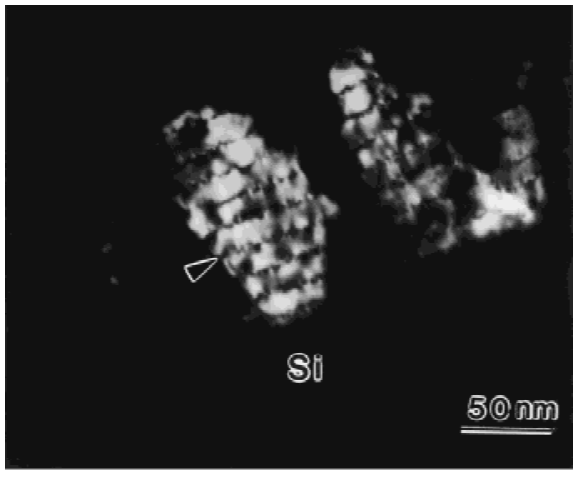

(b)

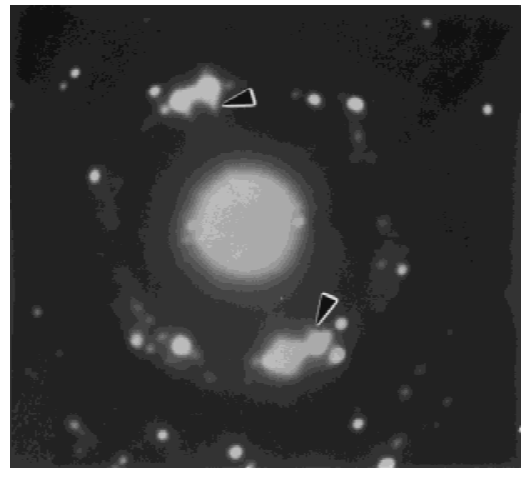

(c)

FIG. 1. Cross-section TEM micrographs of Al-Ti multilayers on Si: (a) bright-field image and (b) dark-field image, showing evidence of columnar grain structure; (c) diffraction pattern showing $\{111\} \mathrm{Al}$ or $\{0002\} \mathrm{Ti}$ spots streaking perpendicular to the Al-Ti interface. Misfit strain contrast is observed at the Al-Ti interfaces (shown with arrow) in Fig. 1(b). 
(overlapping) are insignificant, similar to what has been reported by van Hardeen et al. ${ }^{30}$ JCPDS XRD data $^{31}$ of randomly oriented $\mathrm{Al}$ show that $\{111\} \mathrm{Al}$ peak has the maximum intensity $\left(I_{\{111\} \mathrm{Al}}=I_{\mathrm{max}}\right)$, while $\{200\} \mathrm{Al}$ has $47 \%$ of the maximum intensity, and other peaks have intensities lower than that. In Fig. 2(a), the ratio, $I_{\{200\} \mathrm{Al}} I_{\{111\} \mathrm{A}} \ll 0.47$, and hence the XRD observations of only one $\{111\} \mathrm{Al} /\{0002\} \mathrm{Ti}$ peak of significance confirm the presence of texture of $\{111\}_{\mathrm{Al}, \mathrm{fcc}} / /$ $\{0001\}_{\mathrm{Ti}, \mathrm{hcp}} / /$ film normal.

The diffraction ring corresponding to $\{111\} \mathrm{Al}$ and $\{0002\} \mathrm{Ti}$ in Fig. 2(b) has much higher intensity compared to the rings corresponding to other planes. However, the presence of other diffraction rings of comparatively faint intensity implies that not all grains
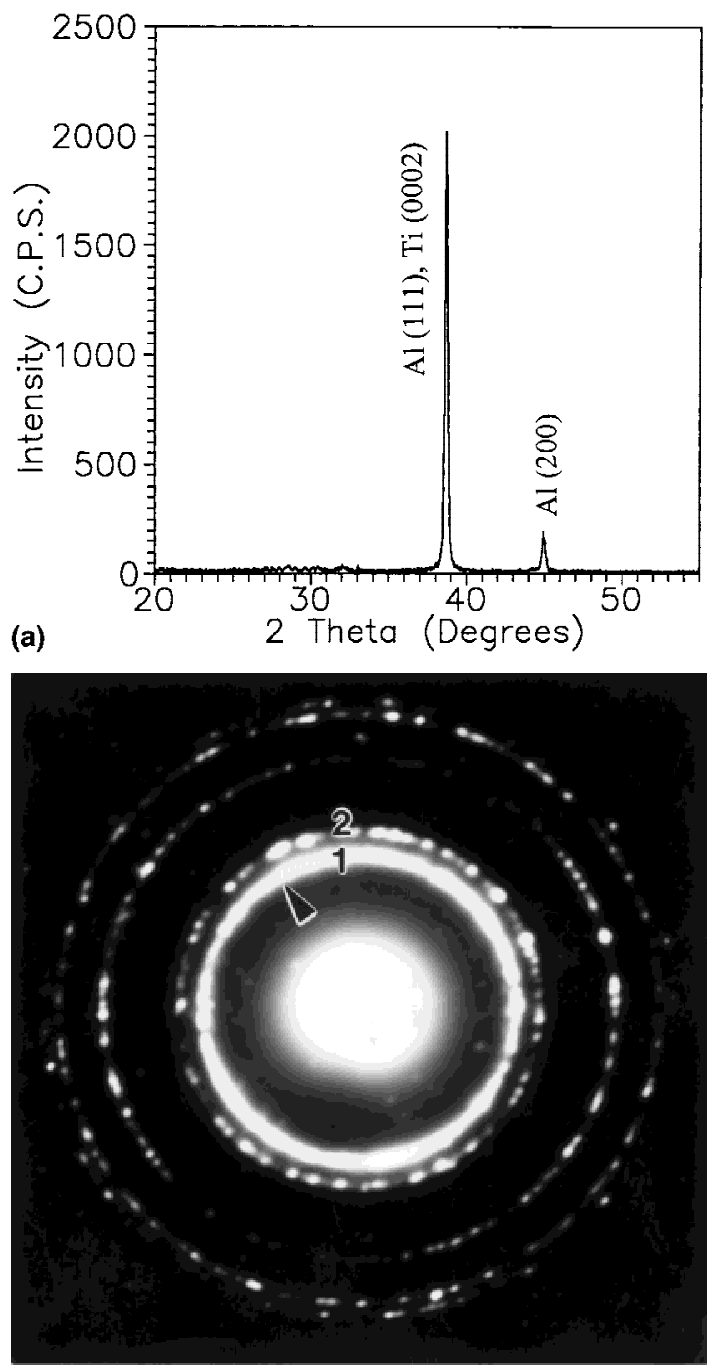

(b)

FIG. 2. (a) X-ray diffraction pattern and (b) electron diffraction pattern from plan-view TEM specimen of as-deposited Al-Ti multilayered film. $\{111\} \mathrm{Al}$ diffraction ring, which coincides with the $\{0002\} \mathrm{Ti}$, is marked as " 1 " is shown with an arrow. The $\{200\} \mathrm{Al}$ ring is marked as " 2 ". of Al have $\{111\}$ planes as parallel to the surface of the film. During HRTEM work on cross-section TEM, it was found that most of the $\mathrm{Al}$ grains had $\{110\}$ zone axis orientation, parallel to the transmitted electron beam, with $\{111\} \mathrm{Al}$ and $\{0002\} \mathrm{Ti}$ planes perpendicular to the direction of film growth, as shown in the cross-section HRTEM image of Fig. 3. However in some areas, the grains were differently oriented, as a result of which either the lattice fringes could not be seen at all, or those corresponding to only one set of $\{111\}$ planes could be resolved. In other words, some fraction of the grains is randomly oriented, quantitative assessment of which was outside the scope of this study.

In Fig. 3, Al has a face-centered-cubic (fcc) structure (close to the [110] zone axis), whereas Ti shows a hexagonal-close-packed (hcp) structure (close to 2110$]$ zone axis), as confirmed from fast Fourier transforms (FFT) of the lattice images of $\mathrm{Al}$ and Ti. The closepacked planes, (111) $\mathrm{Al}$ and (0002) $\mathrm{Ti}$, are parallel at the interface, which is due to their low lattice mismatch $\left[\left(d_{\{111\} \mathrm{Al}}-d_{\{0002\} \mathrm{Ti}}\right) / d_{\{111\}}\right]$ of $0.16 \%(d=$ interplanar spacing). Interface dislocations can be observed in the HRTEM image of $\mathrm{Al} / \mathrm{Ti}$ interface (shown with arrows in Fig. 3), but characterization of misfit or threading dislocations was not carried out.

Both the XRD and ED patterns [Figs. 2(a) and 2(b)], and the FFT of lattice images of $\mathrm{Al}$ and Ti in Fig. 3 have shown that Al has fcc structure and Ti has hep structure. Peaks in XRD patterns or diffraction spots in ED patterns corresponding to $d$-spacings of fcc $\mathrm{Ti}^{30}$ could not be observed. There appears to be a controversy in the literature about the observation of metastable fcc Ti phase. Ahuja and Fraser ${ }^{24}$ and Banerjee et al. ${ }^{25,28,32}$ have shown that both $\mathrm{Al}$ and $\mathrm{Ti}$ may have fcc and hep structure, depending on the bilayer period and volume fraction of

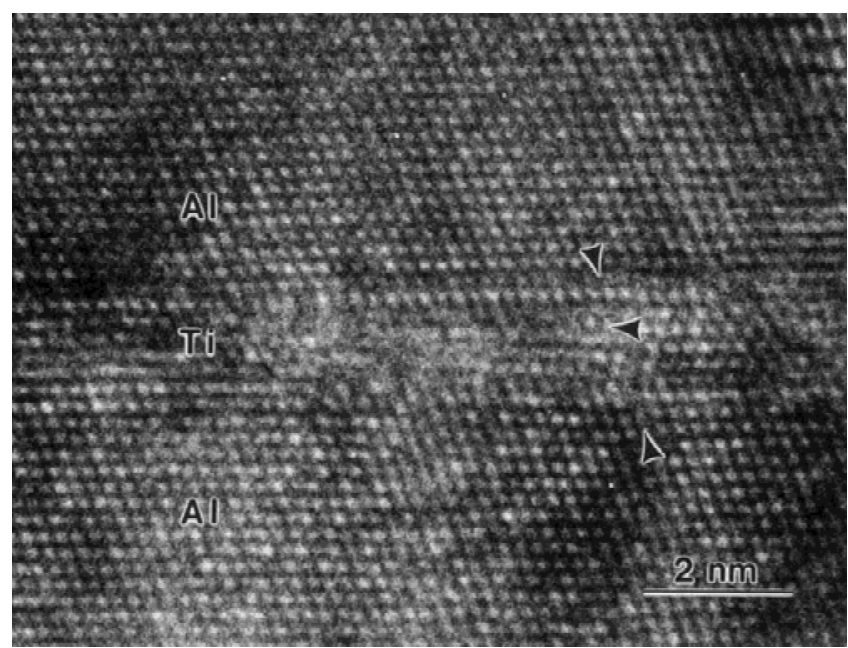

FIG. 3. Cross-section HREM image of Al-Ti interface. Al and Ti lattices are close to [110] and [ $\overline{2} 110]$ zone axes, respectively. Interface dislocations are shown with arrows. 
$\mathrm{Ti}$ in the Al-Ti bilayer. On the other hand, Bonevich et $a .^{29}$ have argued that the appearance of fcc $\mathrm{Ti}$ is an artifact of TEM specimen preparation by ion-milling, because evidence of fcc Ti could be observed only in crosssection TEM samples prepared by ion-milling and not in the XRD patterns of the same samples. ${ }^{29,30}$ In the present situation, hcp Ti was observed even in the cross-section samples prepared by argon ion-milling. Banerjee et al. ${ }^{25,32}$ have proposed a biphase stability diagram (reciprocal of bilayer thickness vs composition) for Ti/Al multilayers. In the biphase diagrams, a thermodynamic mode $^{33}$ for explaining structural stability in multilayers, has been developed first considering reduction in the interfacial energy, ${ }^{32}$ and further modified to account for the effect of interfacial coherency strains on phase stability. ${ }^{25}$ In the present situation, $1 / \lambda=0.067$ and volume fraction of $\mathrm{Ti}, f_{\mathrm{Ti}}=0.12$, for which the phase stability diagram derived by Banerjee et $a .^{25}$ shows that fcc Al and hcp Ti with a coherent interface are stable. However, the interface appears to be semicoherent with misfit strain localization [Fig. 1(b)], even if the crystal structure matches the prediction of the phase diagram perfectly.

\section{B. Effect of annealing on microstructure}

Annealing of the multilayered structure at 350 or $400{ }^{\circ} \mathrm{C}$ leads to disruption of the layered structure by interdiffusion of $\mathrm{Ti}$ and $\mathrm{Al}$, followed by a chemical reaction to form $\mathrm{Al}_{3}$ Ti. Figure 4(a) shows an electron diffraction (ED) pattern from an Al-Ti multilayered film annealed at $350{ }^{\circ} \mathrm{C}$ for $2 \mathrm{~h}$, while Figs. 4(b) and 4(c) show XRD and ED patterns from samples annealed at $400{ }^{\circ} \mathrm{C}$ for 4 and $8 \mathrm{~h}$, respectively. Spots (ED) or peaks (XRD) corresponding to $\mathrm{Al}$ and $\mathrm{Al}_{3} \mathrm{Ti}$ can be seen. The XRD pattern in Fig. 4(b) is presented with the $\{111\} \mathrm{Al}$ peak truncated to magnify the relatively smaller $\mathrm{Al}_{3} \mathrm{Ti}$ peaks. Figures 4(a)-4(c) are typical of such patterns obtained in this study for annealing at 350 and $400{ }^{\circ} \mathrm{C}$ for different periods of time. EDS was carried out on some of the plan-view TEM samples, and $\mathrm{Al}$ and $\mathrm{Ti}$ peaks were observed almost everywhere, indicating that $\mathrm{Al}_{3} \mathrm{Ti}$ precipitation took place in a uniform manner. As the precipitates were fine and embedded in the $\mathrm{Al}$ matrix, overlapping of $\mathrm{Al}$ and $\mathrm{Al}_{3} \mathrm{Ti}$ did not allow accurate EDS quantitative analysis. The chemical reaction resulting in the precipitation of fine $\mathrm{Al}_{3} \mathrm{Ti}$ recipitates has the form:

$$
3 \mathrm{Al}+\mathrm{Ti} \rightarrow \mathrm{Al}_{3} \mathrm{Ti}
$$

Formation of $\mathrm{Al}_{3} \mathrm{Ti}$ has been observed earlier in $\mathrm{Al}-\mathrm{Ti}$ bilayered and multilayered films. ${ }^{3,5,11} \mathrm{Al}_{3} \mathrm{Ti}$ is thermodynamically the most stable Al-Ti intermetallic compound, with a free energy of formation of $-131 \mathrm{~kJ} / \mathrm{mol}$ at $400{ }^{\circ} \mathrm{C}^{34}$ Formation of $\mathrm{Al}_{3} \mathrm{Ti}$ has been attributed to the ease of nucleation and kinetic considerations. ${ }^{3,5,11}$ In a large number of such bilayered or multilayered films, such as $\mathrm{Al}-\mathrm{Zr},{ }^{7} \mathrm{Al}-\mathrm{Hf},{ }^{15} \mathrm{Al}-\mathrm{Ni},{ }^{13}$ etc., the phase with the maximum $\mathrm{Al}$ content nucleates first. The rule proposed by Bené for solid state nucleation states that "the first phase nucleated in metal-metal thin film reactions is the phase immediately adjacent to the lowest temperature liquidus in the binary phase diagram." ${ }^{35} \mathrm{As} \mathrm{Al}$ is the lower melting point metal in $\mathrm{Al}-\mathrm{Ti}$ and other abovementioned binary systems, an Al-rich phase is expected to be the initial phase. On the other hand, Colgan and Mayer ${ }^{9}$ have suggested a theory based on the fact that $\mathrm{Al}$ is the dominant diffusing species during the initial phase formation, which leads to precipitation of the most Alrich phase. Al has been found to be the dominant diffusing species by marker measurements ${ }^{4}$ in bulk systems as well as in thin films. ${ }^{18,19}$ Other studies ${ }^{6,10,11,15}$ of annealing of Ti/Al films or bilayers have revealed that both $\mathrm{Al}$ and $\mathrm{Ti}$ are diffusing species. In the present situation, interdiffusion precedes chemical reaction and nucleation of the $\mathrm{Al}_{3} \mathrm{Ti}$ phase, and disrupts the Al-Ti multilayered structure [Figs. 5(a)-5(c)]. This is the reason why little $\mathrm{Al}_{3} \mathrm{Ti}$ appears as a reaction layer at the $\mathrm{Al}-\mathrm{Ti}$ interlayer interface. However occasionally $\mathrm{Al}_{3} \mathrm{Ti}$ precipitates were found to be localized at the positions of pre-existing $\mathrm{Ti}$ layers in the Al-Ti film annealed at $350^{\circ} \mathrm{C}$ for $2 \mathrm{~h}$ [Fig. 5(a)]. Most of the $\mathrm{Al}_{3} \mathrm{Ti}$ precipitates, however appear evenly distributed in the annealed samples.

Electron and x-ray diffraction analyses [Figs. 4(a)4(c)] have shown that the majority of the $\mathrm{Al}_{3} \mathrm{Ti}$ precipitates in the samples annealed at 350 and $400{ }^{\circ} \mathrm{C}$ for $2 \mathrm{~h}$ or more possess an ordered $\mathrm{DO}_{22}$ structure with lattice parameters of $a=0.385837 \mathrm{~nm}$ and $c=0.85839 \mathrm{~nm}$. However a metastable cubic $\mathrm{L}_{2} \mathrm{Al}_{3} \mathrm{Ti}$ phase could be observed in certain locations in the sample annealed at $350{ }^{\circ} \mathrm{C}$ for $2 \mathrm{~h}$, particularly along pre-existing Ti layers, or among the fine precipitates located inside the $\mathrm{Al}$ grains [Fig. 5(a)]. Figure 6 is the typical electron diffraction pattern from regions with $\mathrm{Al}_{3}$ Ti precipitates in Fig. 5(a), and Fig. 7 is a HRTEM image showing the $\mathrm{L1}_{2} \mathrm{Al}_{3} \mathrm{Ti}$ precipitate, which overlap with another $\mathrm{Al}$ grain. ${\mathrm{The} \mathrm{L} 1_{2}}_{2}$ $\mathrm{Al}_{3} \mathrm{Ti}$ precipitate in Fig. 7 is around $10 \mathrm{~nm}$ in size. Figures 6 and 7 show that the orientation relationship between $\mathrm{Al}$ grain $(\mathrm{Al})$ and $\mathrm{L1}_{2} \mathrm{Al}_{3} \mathrm{Ti}$ precipitates $(\mathrm{P})$ is (100)Al//(100)p and [100]Al//[100]p, which is similar to that reported earlier. ${ }^{35}$ The interface between $\mathrm{L1}_{2} \mathrm{Al}_{3} \mathrm{Ti}$ and $\mathrm{Al}$ is coherent, as shown in Fig. 7. The observation of very fine $\mathrm{Ll}_{2}$ structured $\mathrm{Al}_{3} \mathrm{Ti}$ particles along the preexisting Ti layers implies that the initial phase has a metastable structure. A cubic $\mathrm{L1}_{2} \mathrm{Al}_{3} \mathrm{Ti}$ phase was also observed to form at initial stages of annealing of Al-Ti films by Hong et al. ${ }^{15}$ and Michaelsen et al. ${ }^{20}$ The $\mathrm{L}_{2}$ $\mathrm{Al}_{3} \mathrm{Ti}$ phase with lattice parameter of $0.398 \mathrm{~nm}^{15}$ or $0.405 \mathrm{~nm}^{36}$ close to that of $\mathrm{Al}(0.40496 \mathrm{~nm})$ is easier to nucleate because of the structural coherence and lower interfacial energy, ${ }^{20}$ and has the stoichiometric composition. Hong et al.'s data ${ }^{15}$ indicate that the transition 


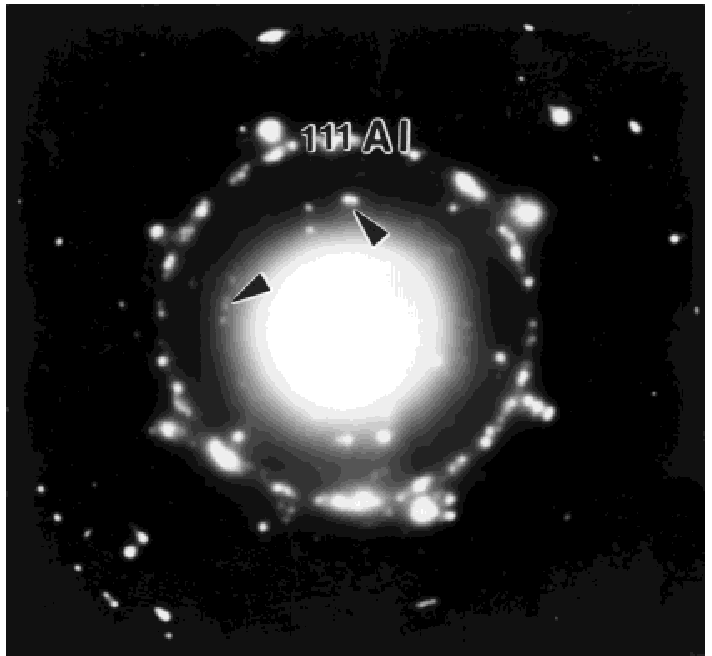

(a)
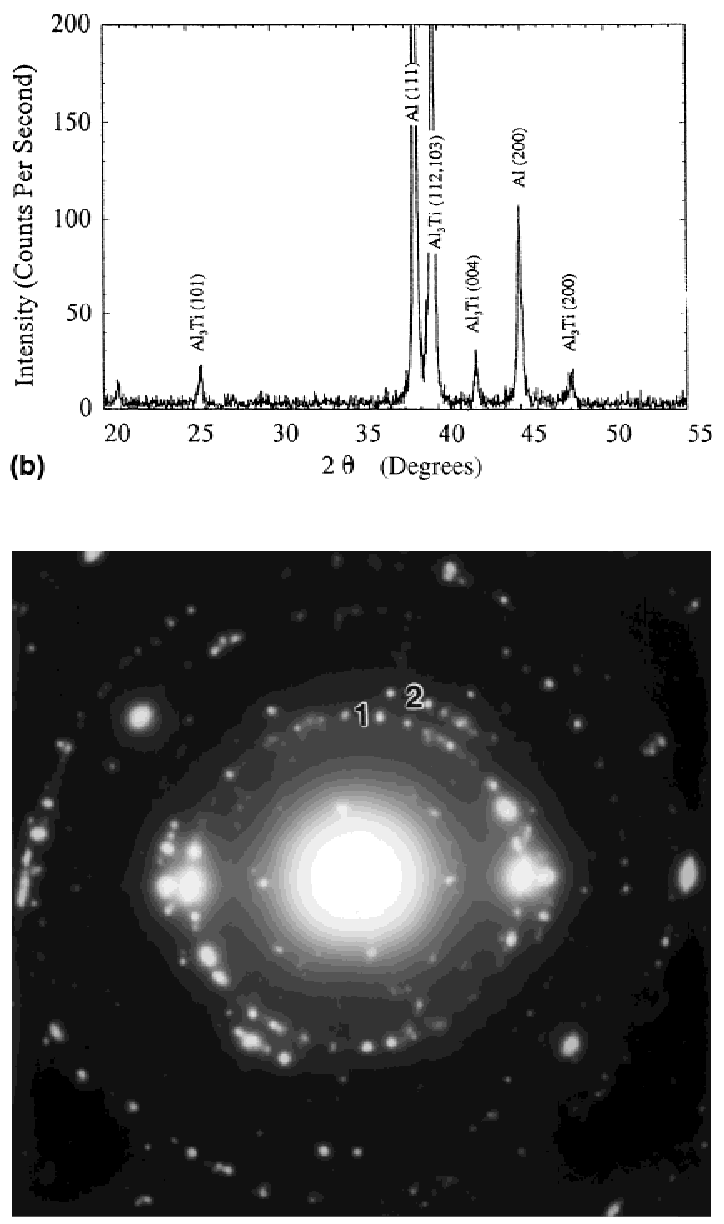

(c)

FIG. 4. (a) Electron diffraction pattern from cross-section sample of $\mathrm{Al}-\mathrm{Ti}$ film annealed at $350{ }^{\circ} \mathrm{C}$ for $2 \mathrm{~h}$, where $\mathrm{DO}_{22} \mathrm{Al}_{3} \mathrm{Ti}$ (101) spots are shown with arrows and evidence of $\{111\} \mathrm{Al}$ texture is visible; (b) XRD pattern from the Al-Ti film after $4 \mathrm{~h}$ of annealing at $400{ }^{\circ} \mathrm{C}$, showing $\mathrm{Al}$ and $\mathrm{Al}_{3} \mathrm{Ti}\left(\mathrm{DO}_{22}\right)$ peaks; and (c) electron diffraction pattern from plan-view sample of Al-Ti film annealed at $400{ }^{\circ} \mathrm{C}$ for $8 \mathrm{~h}$. $\{111\}$ and $\{200\}$ Al rings are marked "1" and "2," respectively. from cubic to tetragonal phase takes place at $450{ }^{\circ} \mathrm{C}$ in an Al-Ti film made by co-evaporation, at $400{ }^{\circ} \mathrm{C}$ in a bilayered $\mathrm{Al}-\mathrm{Ti}$ film, and at lower than $400{ }^{\circ} \mathrm{C}$ in a multilayered $\mathrm{Al}-\mathrm{Ti}$ film. As the $\mathrm{L}_{2} \mathrm{Al}_{3} \mathrm{Ti}$ was found to be more unstable in a multilayered film, it explains why mainly $\mathrm{DO}_{22} \mathrm{Al}_{3} \mathrm{Ti}$ has been found after annealing of Al-Ti multilayered film for $2 \mathrm{~h}$ or more at 350 and $400{ }^{\circ} \mathrm{C}$ in the present work.

The process of breakdown of the layered structure was very gradual and the chemical reactivity of Ti layers was nonuniform. TEM images of cross-section specimens of $\mathrm{Al}-\mathrm{Ti}$ films annealed for $2 \mathrm{~h}$ at 350 or $400{ }^{\circ} \mathrm{C}$ show a highly metastable microstructure with discontinuous strings of residual Ti layers, as well as $\mathrm{Al}_{3} \mathrm{Ti}$ precipitates [Figs. 5(a)-5(c)]. Figures 8(a) and 8(b) show bright-field TEM images from different regions of a cross-section of an Al-Ti film specimen annealed at $400{ }^{\circ} \mathrm{C}$ for $8 \mathrm{~h}$. The remnants of a layered structure could be observed even in the cross-section TEM specimens of Al-Ti films annealed at $400^{\circ} \mathrm{C}$ for 4 and $8 \mathrm{~h}$ [Fig. 8(a)], similar to what was seen more frequently in the sample annealed for $2 \mathrm{~h}$ [Figs. 5(a)-5(c)].

Evidence of $\{111\} \mathrm{Al}$ texture is found in the diffraction patterns from plan-view or cross-section TEM specimens of samples annealed for $2 \mathrm{~h}$ at $350^{\circ} \mathrm{C}$ [as shown in Fig. 4(a)], where $\{111\} \mathrm{Al}$ ring is very prominent, and $\{200\}$ and other diffraction rings of $\mathrm{Al}$ are missing, or only a few spots can be seen. The texture disappears on annealing for longer periods at 350 or at $400{ }^{\circ} \mathrm{C}$. The $\{200\} \mathrm{Al}$ peak is quite prominent in the XRD pattern shown in Fig. 4(b), and the comparison of peak intensities (from the original XRD pattern containing the untruncated $\{111\} \mathrm{Al}$ peak and $\{200\} \mathrm{Al}$ peaks) show that $I_{\{200\}} / I_{\{111\}}=0.47$, which is the intensity ratio in case of a random orientation sample, as provided in the JCPDS data. ${ }^{31}$ The electron diffraction pattern [Fig. 4(c)] from a plan-view sample annealed at $400{ }^{\circ} \mathrm{C}$ for $8 \mathrm{~h}$ shows intensities distributed more evenly among the diffraction rings of $\mathrm{Al}$. The intensity of $\{200\} \mathrm{Al}$ diffraction ring relative to that of $\{111\} \mathrm{Al}$ is much higher in Fig. 4(c), when compared to that in Figs. 4(a) and 2(b).

Al grains change their morphology on annealing, as seen by TEM examination of cross-section specimens. After $2 \mathrm{~h}$ of annealing at 350 and $400{ }^{\circ} \mathrm{C}$, they appeared elongated along the pre-existing $\mathrm{Al}$ layer [as shown in Fig. 5(c)]. With increase in the time of annealing at 350 and $400{ }^{\circ} \mathrm{C}$, the $\mathrm{Al}$ grain changed to a more irregular or equiaxed shape [Figs. 8(b), 9(a), and 9(b)]. Figs. 9(a) and 9(b) are plan-view dark-field TEM images of $\mathrm{Al}-\mathrm{Al}_{3} \mathrm{Ti}$ composite after 4 and $24 \mathrm{~h}$ of annealing at $400{ }^{\circ} \mathrm{C}$, obtained by beam-tilting to the centre a part of the $\{111\} \mathrm{Al}$ ring of the electron diffraction pattern. The $\mathrm{Al}$ grains and $\mathrm{Al}_{3}$ Ti particles in the sample annealed for $24 \mathrm{~h}$ at $400{ }^{\circ} \mathrm{C}$ appear slightly larger than those in the sample annealed for $4 \mathrm{~h}$. Considering that there was 12 at.\% $\mathrm{Ti}$ in the 
as-deposited Al-Ti films, and that all of the $\mathrm{Ti}$ is consumed in $\mathrm{Al}_{3} \mathrm{Ti}$ formation, the volume fraction of $\mathrm{Al}_{3} \mathrm{Ti}$ obtained in the equilibrium composite microstructure as obtained by calculation is $47 \%$. This is the maximum volume fraction of $\mathrm{Al}_{3} \mathrm{Ti}$ possible when the Ti layers disappear completely and the whole of Ti is reacted. The volume fraction of $\mathrm{Al}_{3} \mathrm{Ti}$ could not be measured by quantitative microscopy in the TEM as it was very high. In the samples annealed for smaller periods, such as $2 \mathrm{~h}$ at 350 or $400{ }^{\circ} \mathrm{C}$, which showed discontinuous $\mathrm{Ti}$ layers, the volume fraction of $\mathrm{Al}_{3} \mathrm{Ti}$ appeared less. While the finer $\mathrm{Al}_{3} \mathrm{Ti}$ particles in the $\mathrm{Al}-\mathrm{Ti}$ films were located mostly
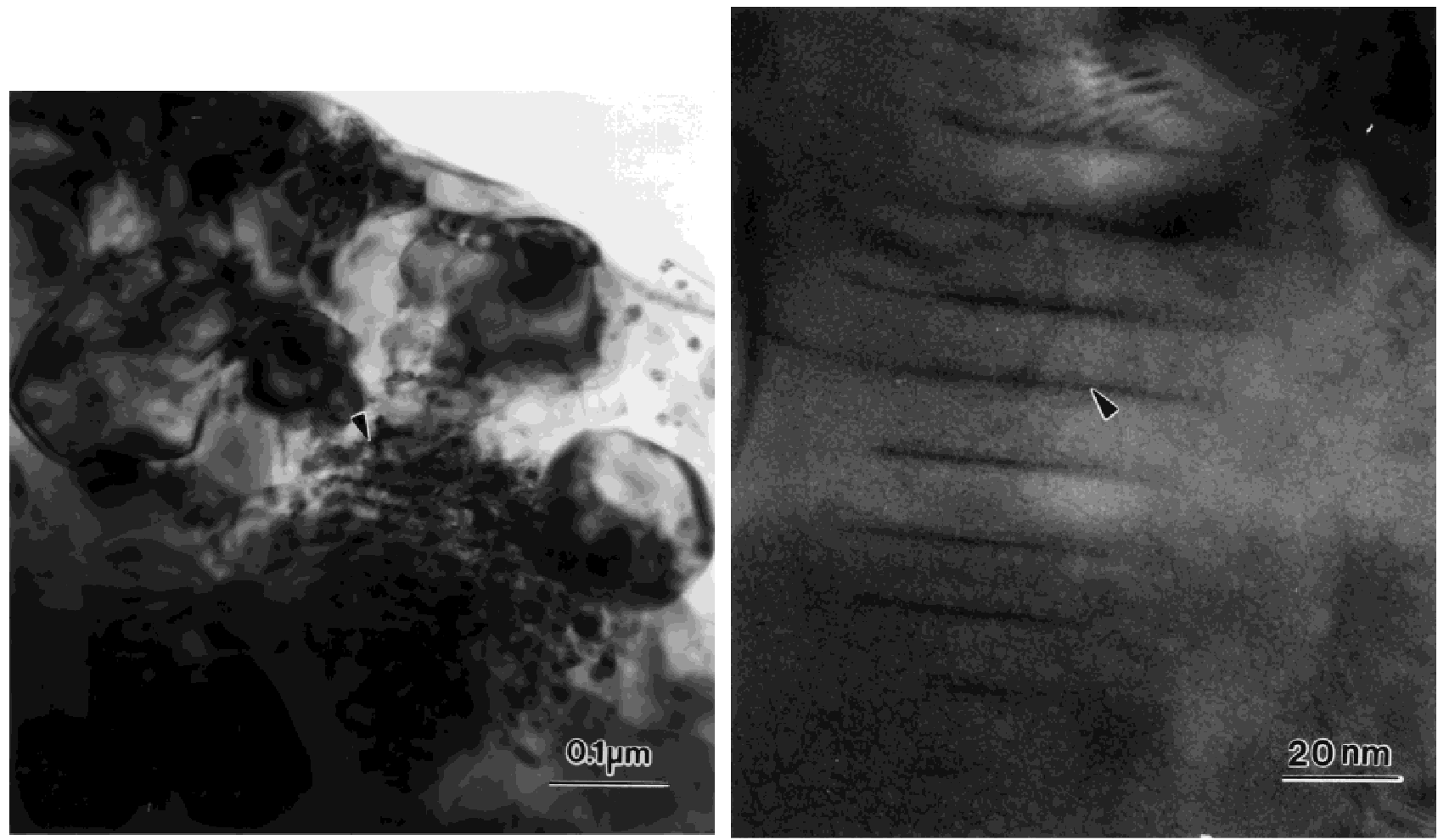

(a)

(b)

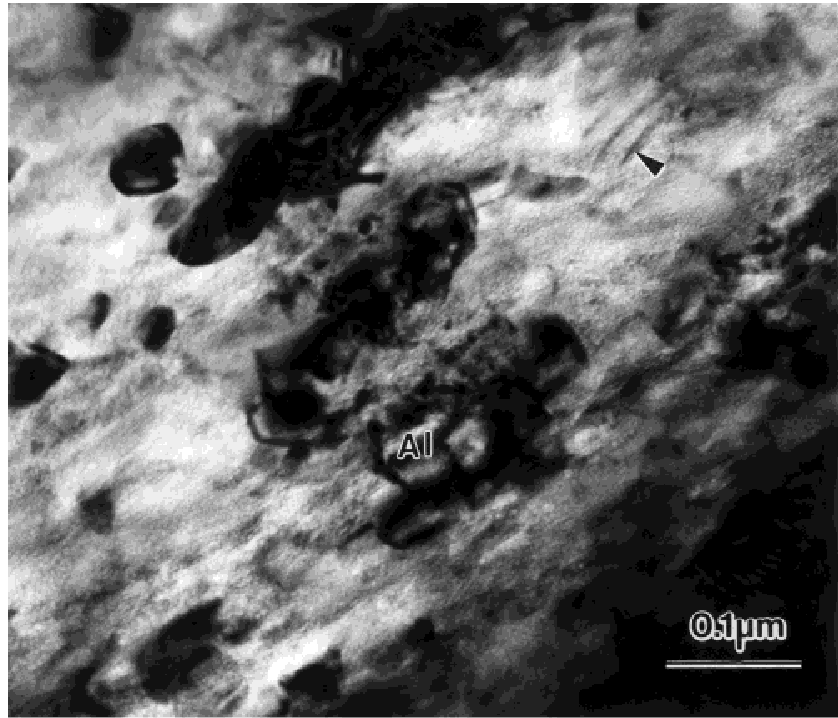

(c)

FIG. 5. Cross-section TEM micrographs of Al-Ti multilayered film after annealing for $2 \mathrm{~h}$, showing evidence of pre-existing Ti layers: (a) bright-field image of sample annealed at $350{ }^{\circ} \mathrm{C}$ (layers with $\mathrm{Al}_{3}$ Ti precipitates arrowed); (b) HREM image of sample annealed at $400{ }^{\circ} \mathrm{C}$ showing unreacted Ti layers (indicated by an arrow); (c) bright-field image of sample annealed at $400{ }^{\circ} \mathrm{C}$ showing unreacted Ti layers (arrowed) and $\mathrm{Al}$ grains (marked as "Al") formed along pre-existing layers (shown with arrow). 
inside the $\mathrm{Al}$ grains [Fig. 5(a)], the coarser $\mathrm{Al}_{3} \mathrm{Ti}$ particles in the films were located at the $\mathrm{Al}$ grain boundaries [Fig. 8(b)]. Growth in the sizes of $\mathrm{Al}$ grains and $\mathrm{Al}_{3} \mathrm{Ti}$ precipitates was slightly more at 400 than at $350{ }^{\circ} \mathrm{C}$. The grain and particle size distributions are well described by a log-normal relationship. The log-normal distribution function, $f(x)$ is expressed as ${ }^{37}$

$$
f(x)=1 /\left\{\sqrt{ }(2 \pi) \mathrm{x} s_{\ln x}\right\} \cdot\left[\exp \left\{-1 / 2\left[\left(\ln x-m_{\ln x}\right) / s_{\ln x}\right]^{2}\right\}\right],
$$

where $x$ represents grain or particle size, and the $m_{\ln x}$ and $s_{\ln x}$ are respectively the mean and standard deviations of $\ln x$. The mean grain size in the lognormal distribution is given by:

$$
m_{\mathrm{x}}=\exp \left(m_{\ln x}+s_{\ln x}^{2} / 2\right) .
$$

Distributions of number fractions of $\mathrm{Al}$ grain and $\mathrm{Al}_{3} \mathrm{Ti}$ particle sizes were studied for conditions corresponding to different annealing times at 350 and $400{ }^{\circ} \mathrm{C}$. Figures 10 (a) $-10(\mathrm{~d})$ are $\log$-normal plots of $\mathrm{Al}$ grain and $\mathrm{Al}_{3} \mathrm{Ti}$ particle size distributions, respectively, obtained from TEM observations of cross-section Al-Ti specimens annealed at 350 and $400{ }^{\circ} \mathrm{C}$. The positions of peak of size distributions of $\mathrm{Al}$ grains and $\mathrm{Al}_{3} \mathrm{Ti}$ precipitates do not alter very remarkably, but the distributions widen with increase in the annealing time. Table I shows the mode and mean values of the $\mathrm{Al}$ grain and $\mathrm{Al}_{3} \mathrm{Ti}$ particle size distributions obtained from the TEM studies of planview and cross-section specimens of $\mathrm{Al}-\mathrm{Ti}$ films annealed at 350 and $400{ }^{\circ} \mathrm{C}$.

It is noted that the peak grain sizes of the distribution of the $\mathrm{Al}$ grains and $\mathrm{Al}_{3} \mathrm{Ti}$ precipitates obtained from cross-section TEM study of specimens annealed

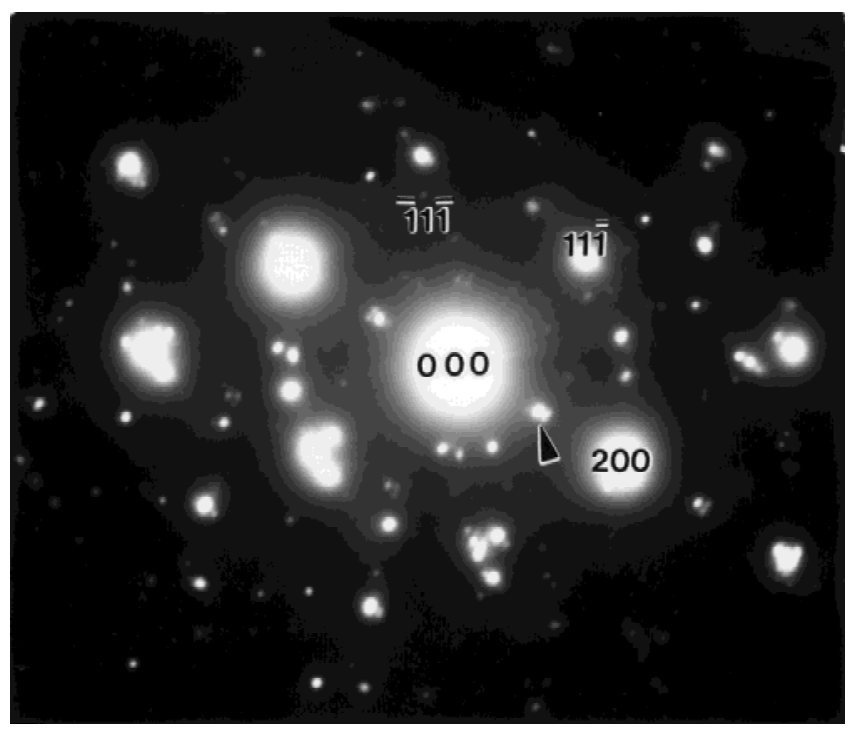

FIG. 6. Typical electron diffraction pattern close to [011] Al zone axis from region containing $\mathrm{Al}_{3} \mathrm{Ti}$ precipitates in Fig. 5(a), showing presence of $\mathrm{Ll}_{2} \mathrm{Al}_{3} \mathrm{Ti}$ precipitates. $\mathrm{L}_{2} \mathrm{Al}_{3} \mathrm{Ti}$ (100) spot is shown with arrow. at $400{ }^{\circ} \mathrm{C}$ are close to, but not the same as, those from plan-view study. The difference is possibly due to variation of sample size used. As the volume fraction of $\mathrm{Al}_{3} \mathrm{Ti}$ increases with the increase in the annealing time, the size distribution also widens. The mean and mode of the size distribution do not represent any unique size of $\mathrm{Al}$ grains or $\mathrm{Al}_{3} \mathrm{Ti}$ particles in a particular microstructure. The $\mathrm{Al}_{3} \mathrm{Ti}$ precipitates located at grain boundaries of $\mathrm{Al}$ [Fig. 8(b)] tend to restrict grain growth by a grain boundary pinning mechanism.

\section{DTA Studies}

The present DTA studies show that the chemical reaction of Eq. (2) takes place exothermically between 320 and $390{ }^{\circ} \mathrm{C}$ for heating rates between 2 and $25^{\circ} \mathrm{C} /$ minute (Fig. 11). Published studies ${ }^{11,15}$ suggest that the $\mathrm{Al}_{3} \mathrm{Ti}$ formation takes place at and above $350{ }^{\circ} \mathrm{C}$, without any discussion of the role of heating rates. In the present investigation, the peaks are due to the heat evolved in the exothermic reaction and positions show the temperature or the range of temperatures at which the exothermic reaction takes place. The sharpest peak was observed when the smallest heating rate of $2{ }^{\circ} \mathrm{C} /$ minute was used. No peak was observed in the curve representing the heating of a pure Al film, strongly suggesting that the heat evolved in the peaks is only due to the chemical reaction between $\mathrm{Al}$ and $\mathrm{Ti}$. The curves corresponding to multilayered structure also show minor fluctuations as compared to that of pure $\mathrm{Al}$ film, which are possibly due to relaxation of residual strains of the individual Al-Ti layers during heating. The peak of the reaction exotherms in the Al-Ti films moves to higher temperatures as the

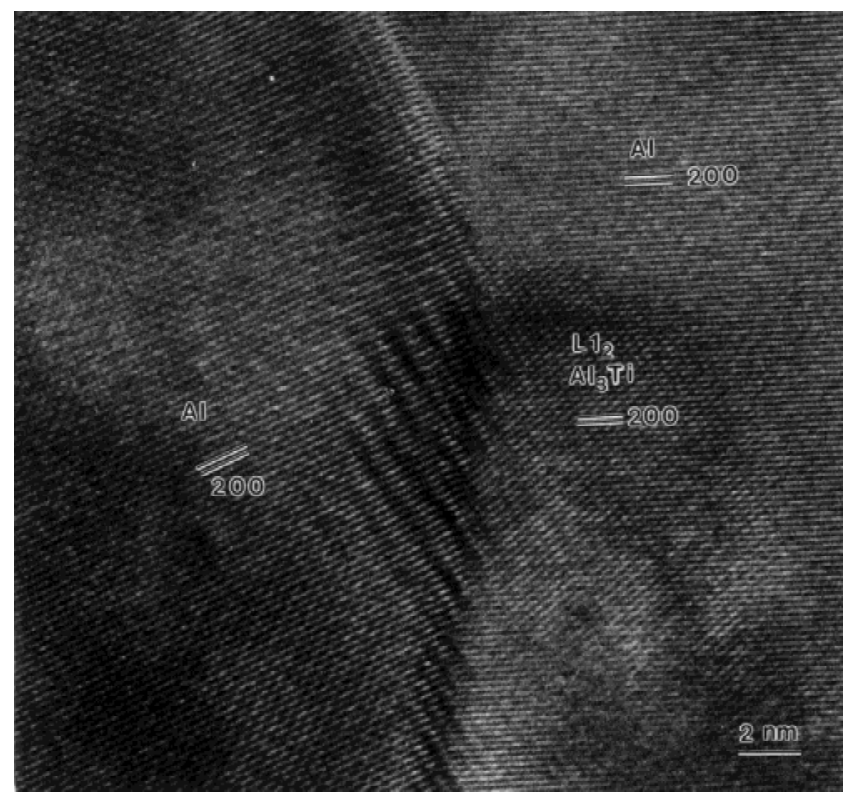

FIG. 7. High-resolution TEM image showing the coherent interface between $\mathrm{Al}$ and $\mathrm{Ll}_{2} \mathrm{Al}_{3} \mathrm{Ti}$. The orientation relationship is (100)Al// (100) $\mathrm{Al}_{3} \mathrm{Ti}$ and [100] $\mathrm{Al} / /[100] \mathrm{Al}_{3} \mathrm{Ti}$. 
heating rate is increased. The increase in the temperature of the exotherm with an increase in the heating rate implies that there is an activation barrier for the chemical reaction, which could possibly be linked with the nucleation of the $\mathrm{Al}_{3} \mathrm{Ti}$ phase. The activation barrier for $\mathrm{Al}_{3} \mathrm{Ti}$ formation is also apparent from the fact that remnants of the layered structure were found in the Al-Ti film even after annealing at $400{ }^{\circ} \mathrm{C}$ for $8 \mathrm{~h}$. The activation energy has been determined from DTA curves corresponding to different heating rates, using an equation obtained by Kissinger: ${ }^{38}$

$$
\mathrm{d}\left[\ln \left(\varphi / T_{\mathrm{R}}^{2}\right)\right] / \mathrm{d}(1 / T)=-\mathrm{E} / R
$$

where $\varphi$ is the heating rate, $T_{\mathrm{R}}$ is the absolute temperature corresponding to the exothermic or endothermic

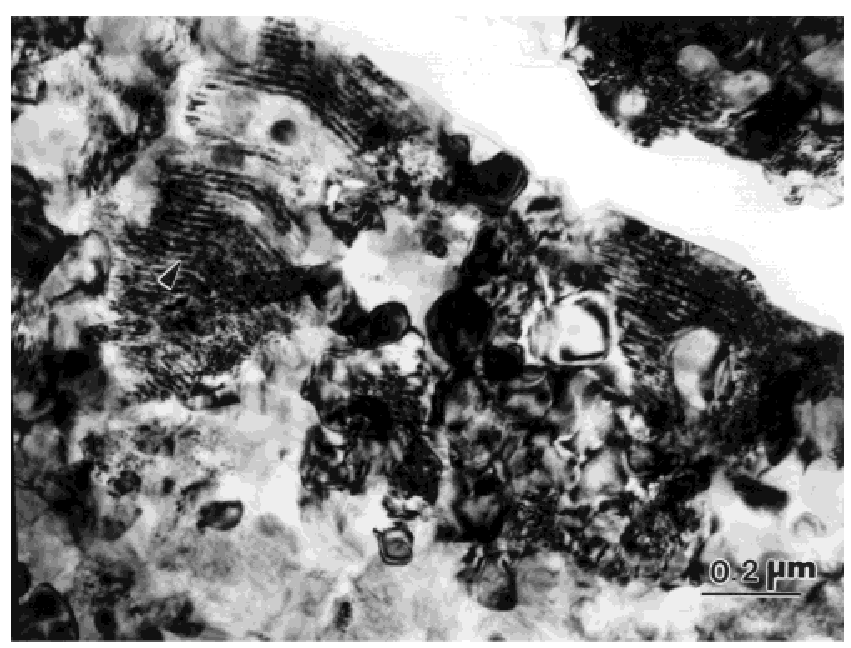

(a)

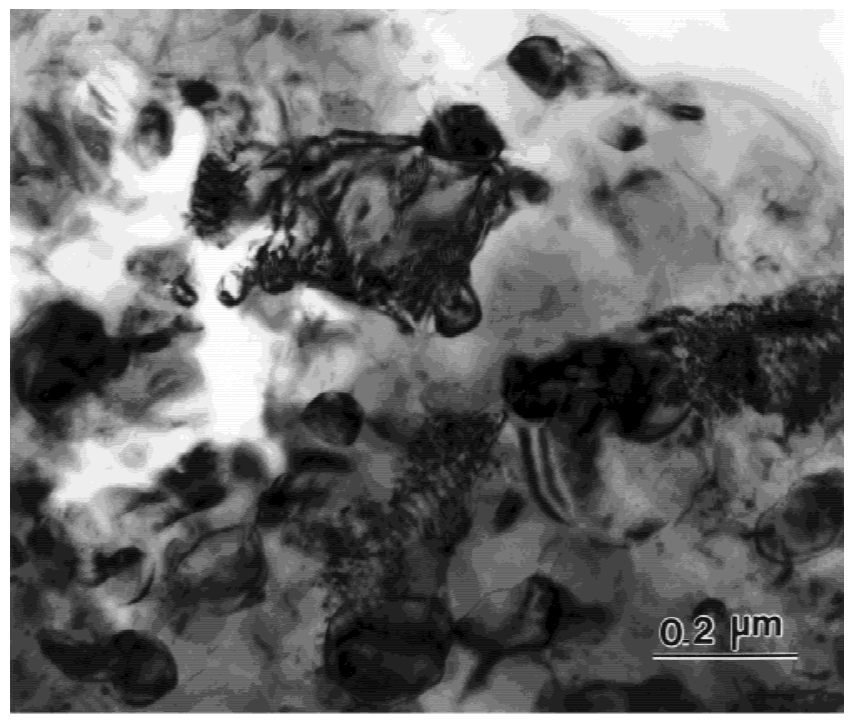

(b)

FIG. 8. Bright-field cross-section TEM image of Al-Ti film annealed for $8 \mathrm{~h}$ at $400^{\circ} \mathrm{C}$, showing: (a) residual $\mathrm{Al}-\mathrm{Ti}$ layered structure (arrowed), and (b) irregularly shaped $\mathrm{Al}$ grain with the $\mathrm{Al}_{3} \mathrm{Ti}$ precipitates at the grain boundary. peak position, $T$ is the absolute temperature of the system, $\mathrm{E}$ is the activation energy, and $R$ is the universal gas constant $\left(8.314 \mathrm{JK}^{-1} \mathrm{~mol}^{-1}\right)$. This equation has been used in the past to obtain the activation energies for phase transformations. ${ }^{39}$ Figure 12 is the Kissinger plot showing the linear variation of $\ln \left(\varphi / T_{\mathrm{R}}{ }^{2}\right)$ with $1 / T_{\mathrm{R}}$. The activation energy calculated from the slope of the best-fit line is $106.5 \mathrm{kJK}^{-1} \mathrm{~mol}^{-1}(1.1 \mathrm{eV})$. It is noted that the activation energy of $\mathrm{Al}_{3} \mathrm{Ti}$ formation determined here

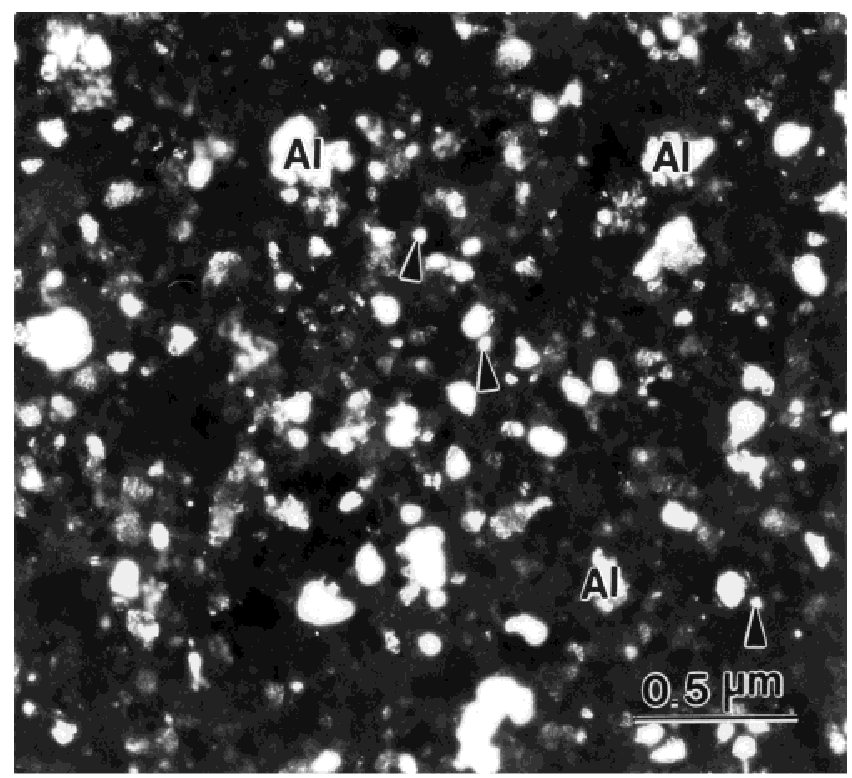

(a)

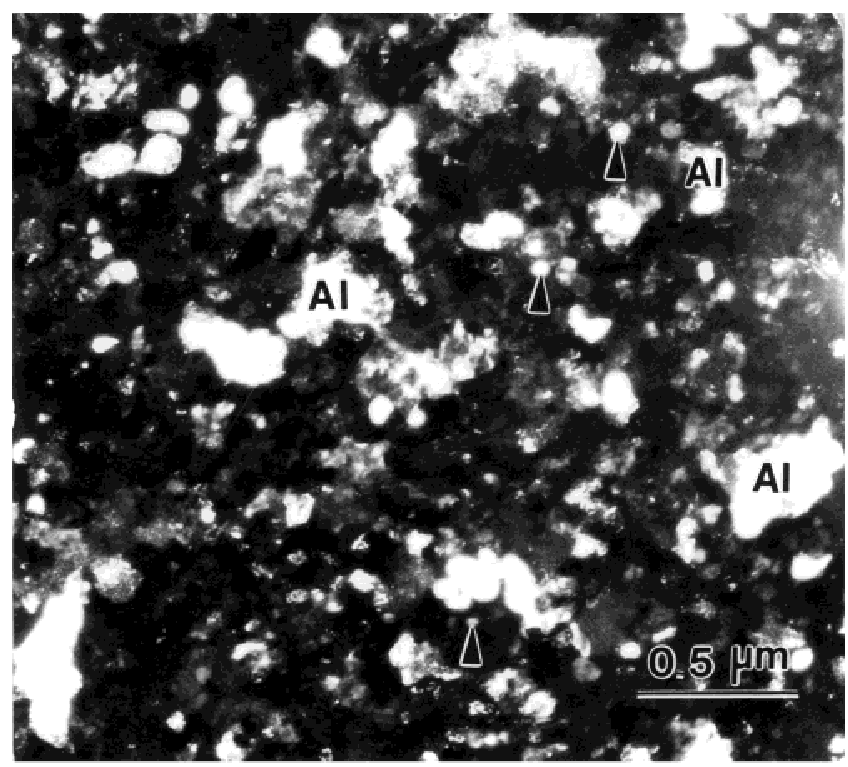

(b)

FIG. 9. Dark field plan-view TEM images of Al-Ti multilayered films annealed at $400{ }^{\circ} \mathrm{C}$ for (a) $4 \mathrm{~h}$ and (b) $24 \mathrm{~h}$, obtained from a segment of the $\{111\} \mathrm{Al}$ ring in the corresponding electron diffraction pattern, which was centered using beam-tilt. Some of the Al grains are identified with "Al," while $\mathrm{Al}_{3} \mathrm{Ti}$ particles are shown with arrows. 

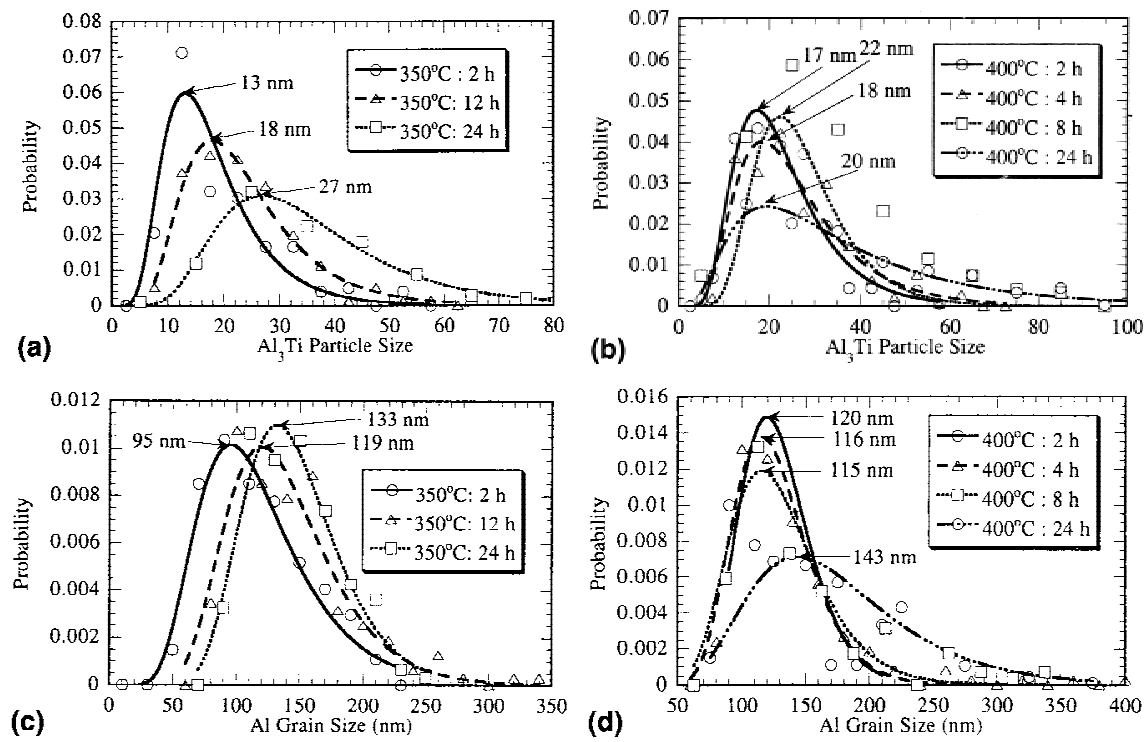

FIG. 10. Log-normal plots of number fraction of size distributions obtained from cross-section TEM observations of: $\mathrm{Al}_{3} \mathrm{Ti}$ particles on annealing at (a) $350{ }^{\circ} \mathrm{C}$ and (b) $400{ }^{\circ} \mathrm{C}$; and $\mathrm{Al}$ grains on annealing at (c) $350{ }^{\circ} \mathrm{C}$ and (d) $400{ }^{\circ} \mathrm{C}$.

TABLE I. Mean and mode values of log normal distributions of $\mathrm{Al}$ grain size and $\mathrm{Al}_{3} \mathrm{Ti}$ particle sizes.

\begin{tabular}{|c|c|c|c|c|c|c|c|c|}
\hline \multirow{2}{*}{$\begin{array}{l}\text { Annealing } \\
\text { conditions }\end{array}$} & \multicolumn{2}{|c|}{$\begin{array}{c}\text { Al grain size } \\
\text { plan-view } \\
\text { data }(\mathrm{nm})\end{array}$} & \multicolumn{2}{|c|}{$\begin{array}{l}\text { Al grain size } \\
\text { cross-section } \\
\text { data }(\mathrm{nm})\end{array}$} & \multicolumn{2}{|c|}{$\begin{array}{l}\mathrm{Al}_{3} \mathrm{Ti} \text { size } \\
\text { plan-view } \\
\text { data }(\mathrm{nm})\end{array}$} & \multicolumn{2}{|c|}{$\begin{array}{c}\mathrm{Al}_{3} \mathrm{Ti} \text { size } \\
\text { cross-section } \\
\text { data }(\mathrm{nm})\end{array}$} \\
\hline & Mode & Mean & Mode & Mean & Mode & Mean & Mode & Mean \\
\hline $350^{\circ} \mathrm{C}, 2 \mathrm{~h}$ & 97 & 107 & 95 & 114 & 14 & 17 & 13 & 17 \\
\hline $350^{\circ} \mathrm{C}, 12 \mathrm{~h}$ & 132 & 151 & 119 & 135 & 21 & 26 & 18 & 23 \\
\hline $350^{\circ} \mathrm{C}, 24 \mathrm{~h}$ & 129 & 158 & 133 & 144 & 23 & 28 & 27 & 34 \\
\hline $400^{\circ} \mathrm{C}, 2 \mathrm{~h}$ & $\ldots^{\mathrm{a}}$ & $\ldots^{\mathrm{a}}$ & 120 & 127 & 16 & 18 & 17 & 22 \\
\hline $400^{\circ} \mathrm{C}, 4 \mathrm{~h}$ & 102 & 116 & 116 & 124 & 20 & 24 & 18 & 25 \\
\hline $400^{\circ} \mathrm{C}, 8 \mathrm{~h}$ & 108 & 122 & 115 & 127 & 21 & 25 & 22 & 26 \\
\hline $400^{\circ} \mathrm{C}, 24 \mathrm{~h}$ & 130 & 151 & 143 & 169 & 25 & 29 & 20 & 34 \\
\hline
\end{tabular}

${ }^{a}$ Not enough data for the particular annealing treatment is available for calculation of mode and mean of the distribution.

is less than the activation energies ${ }^{18}$ of diffusion of $\mathrm{Al}$ $\left(1.81 \mathrm{eV}\right.$ or $\left.174.6 \mathrm{kJK}^{-1} \mathrm{~mol}^{-1}\right)$ and $\mathrm{Ti}(1.68 \mathrm{eV}$ or $162 \mathrm{kJK}^{-1} \mathrm{~mol}^{-1}$ ) in $\mathrm{Al}_{3} \mathrm{Ti}$ phase.

\section{Stress measurements}

On an atomic scale, the tensile residual stresses in thin films originate due to interatomic interactions; that is, when the average interatomic distance in the film is greater than the equilibrium value. The tensile stresses increase as isolated islands coalesce and voids are removed in thin metallic films. The stresses in multilayered films can result from several sources, ${ }^{40}$ growth processes, differences in coefficient of thermal expansion (CTE) between film and substrate, coherency strains, interfacial reactions, and the interface stress. The interface stresses $^{41}$ arise from the reversible work per unit area to elastically deform the interface or surface by a unit strain. Interface strain can cause changes in lattice parameter

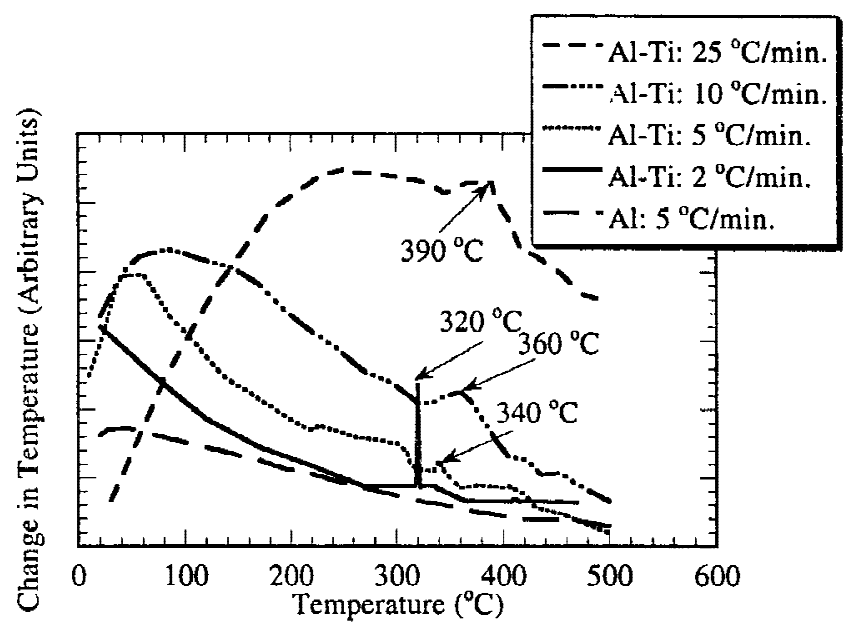

FIG. 11. DTA curves corresponding to heating of free standing Al-Ti multilayered films from room temperature to $500{ }^{\circ} \mathrm{C}$ in argon environment. DTA data of a pure $\mathrm{Al}$ film is included for comparison. 


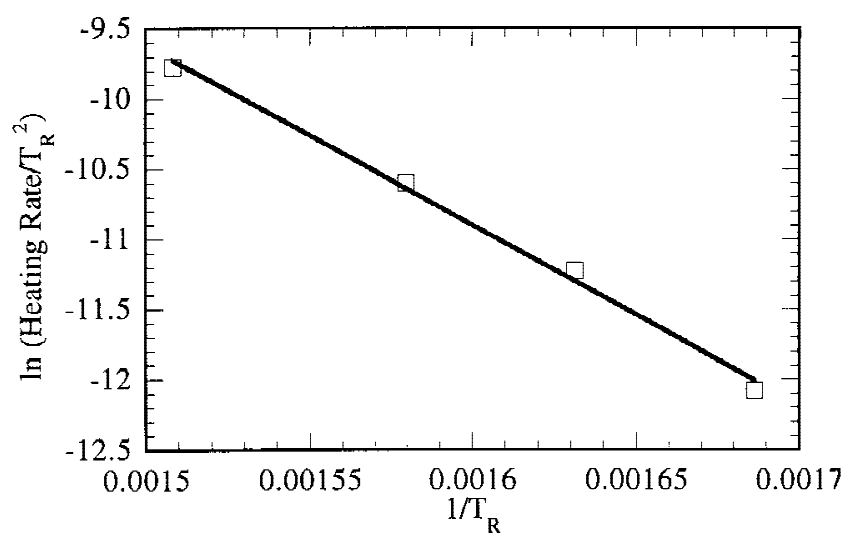

FIG. 12. Kissinger plot for activation energy calculation: variation of $\ln \left(\varphi / T_{\mathrm{R}}{ }^{2}\right)$ with $1 / T_{\mathrm{R}}$, where $\varphi$ is the heating rate, and $T_{\mathrm{R}}$ is the absolute temperature corresponding to the reaction exotherm. The equation of the best-fit line is $y=9.5951-12810 x$ and the coefficient of regression is 0.99744 .

close to the internal interface. The resultant of all the stresses mentioned above contribute to substrate curvature. Ruud et al. ${ }^{40}$ and Misra et $a l^{41}$ found significant contribution from interfacial stresses in $\mathrm{Ag}-\mathrm{Ni}$ and $\mathrm{Cu}-$ $\mathrm{Cr}$ multilayered films, respectively. Bain et $a{ }^{42}$ did not observe a significant contribution from interlayer interfacial stresses in Mo-Ni multilayers, which have an affinity for interphase formation. It has also been observed that coherent interfaces possess lower interface stress as compared to the incoherent ones. ${ }^{42,43}$ The Al-Ti semicoherent interfaces show misfit strain localization [Fig. 1(b)] to minimize the coherency stresses and also have a strong affinity for interphase phase $\left(\mathrm{Al}_{3} \mathrm{Ti}\right)$ formation, which suggests low interface stress.

In the present investigation, the residual stress in the $\mathrm{Al}-\mathrm{Ti}$ multilayered film on a $\mathrm{Si}$ substrate in the asdeposited condition has been found to be tensile with a magnitude of $0.27 \pm 0.01 \mathrm{GPa}$. In the as-deposited state, the residual stresses are primarily intrinsic, that is, growth related. There will be in-plane intrinsic stress in the Al layer, in the Ti layer, and at the $\mathrm{Al} / \mathrm{Ti}$ interface. The sum of all three is what has been measured in the multilayered sample as a tensile $0.27 \pm 0.01 \mathrm{GPa}$.

The tensile residual stress of Al-Ti film after annealing at $350{ }^{\circ} \mathrm{C}$ was found to be $0.27 \pm 0.01 \mathrm{GPa}$. Annealing at $350{ }^{\circ} \mathrm{C}$ for $2 \mathrm{~h}$ is expected to cause stress relief by processes such as diffusion and annihilation of redundant dislocations. Upon cooling, the tensile stress reappears due to other mechanisms, such as (i) phase transformation (precipitation of $\mathrm{Al}_{3} \mathrm{Ti}$ ), which tends to cause volume contraction in the film and (ii) CTE mismatch between metal film and the Si substrate while the film remains rigidly bonded to the substrate and is not free to relax the stress. These mechanisms are discussed below.

Observation of cross-section TEM microstructure of an $\mathrm{Al}-\mathrm{Ti}$ film annealed at $350{ }^{\circ} \mathrm{C}$ for $2 \mathrm{~h}$ showed that the $\mathrm{Al}-\mathrm{Ti}$ multilayered structure is disrupted and interlayer interfaces do not exist in most of the film. Stress enhancement due to the precipitation of $\mathrm{Al}_{3} \mathrm{Ti}$ was earlier reported by Gardner et al. ${ }^{44} \mathrm{Al}_{3}$ Ti has a density of $3.36 \mathrm{~g} / \mathrm{cm}^{3}$, which is higher than the density $\left(2.702 \mathrm{~cm}^{3}\right)$ of pure Al. The unit cell (cubic, fcc) of Al contains 4 atoms and the lattice parameter is $0.40496 \mathrm{~nm}$, while the unit cell (tetragonal, $\mathrm{DO}_{22}$ ) of $\mathrm{Al}_{3} \mathrm{Ti}$ has 8 atoms (6 atoms of $\mathrm{Al}$ and 2 atoms of $\mathrm{Ti}$ ), and the lattice parameters are $a=0.3848 \mathrm{~nm}$ and $c=0.8596 \mathrm{~nm}$. The unit cell (hcp) of Ti has 2 atoms, and the lattice parameters are $a$ $=0.295 \mathrm{~nm}$ and $c=0.4686 \mathrm{~nm}$. Assuming the atoms to be hard spheres, calculations based on the above data show that concentrations of atoms per unit volume of $\mathrm{Al}$, $\mathrm{Ti}$, and $\mathrm{Al}_{3} \mathrm{Ti}$ are $60.24,56.6$, and $62.85 \mathrm{~nm}^{-3}$, respectively, which again imply that $\mathrm{Al}_{3} \mathrm{Ti}$ lattice is the most densely packed. From the above, 6 atoms of $\mathrm{Al}$ (in $\mathrm{Al}$ lattice) would occupy $0.0996 \mathrm{~nm}^{3}$, while 2 atoms of Ti (in Ti lattice) would occupy $0.0353 \mathrm{~nm}^{3}$, which accounts for total volume of $0.1349 \mathrm{~nm}^{3}$. The $\mathrm{DO}_{22}$ unit cell of $\mathrm{Al}_{3}$ Ti containing 6 atoms of $\mathrm{Al}$ and 2 atoms of Ti has a volume $\left(a^{2} c\right)$ of $0.1273 \mathrm{~nm}^{3}$. Hence, $\mathrm{Al}_{3} \mathrm{Ti}$ formation leads to localized volume contraction of $5.6 \%$, which has to be accommodated partly by plastic deformation of the surrounding Al matrix, and elastic strains. The volume strain due to contraction, $\epsilon_{\mathrm{v}}=0.056$ leads to an increase in the dialational tensile residual stress, $\Delta \sigma$ in the film by $K \cdot \epsilon_{\mathrm{v}}=3.15 \mathrm{GPa}$, where $K$ is the bulk modulus of $\mathrm{Al}(\approx 63 \mathrm{GPa})$.

Again cooling of a film from $350{ }^{\circ} \mathrm{C}$ to room temperature can lead to differential contraction of the Si substrate and the film and consequently a tensile residual stress in the film. The CTE's of Si, Al and Ti are $2.49 \times 10^{-6}$, $23.1 \times 10^{-6}$, and $8.6 \times 10^{-6} \mathrm{~K}^{-1}$, respectively. Assuming the rule of mixtures for estimating the CTE of the Al-Ti film, the value obtained is $21.4 \mathrm{~K}^{-1}$. The CTE and elastic constants of the film change further with precipitation of $\mathrm{Al}_{3} \mathrm{Ti}$ particles. Hence it is not possible to accurately determine the CTE of the film. But it is close to 10 times that of Si to begin with and this difference would contribute to the resultant stress.

When the Al-Ti film previously annealed at $350{ }^{\circ} \mathrm{C}$ for $2 \mathrm{~h}$ was further annealed at $400{ }^{\circ} \mathrm{C}$ for $2 \mathrm{~h}$, the tensile residual stress increased to $0.33 \pm 0.02 \mathrm{GPa}$. The increase in the magnitude of the residual stress on annealing at $400{ }^{\circ} \mathrm{C}$ for $2 \mathrm{~h}$ is believed to be due to the precipitation of a higher volume fraction of $\mathrm{Al}_{3} \mathrm{Ti}$ precipitates during annealing at $400{ }^{\circ} \mathrm{C}$, as well as higher differential contraction between the $\mathrm{Si}$ substrate and the $\mathrm{Al}-\mathrm{Al}_{3} \mathrm{Ti}$ composite film.

\section{E. Hardness measurement}

Figure 13 shows the variation of nanoindentation hardness values of $\mathrm{Al}-\mathrm{Ti}$ films on Si substrates with increasing periods of annealing at 350 or $400{ }^{\circ} \mathrm{C}$, along with 


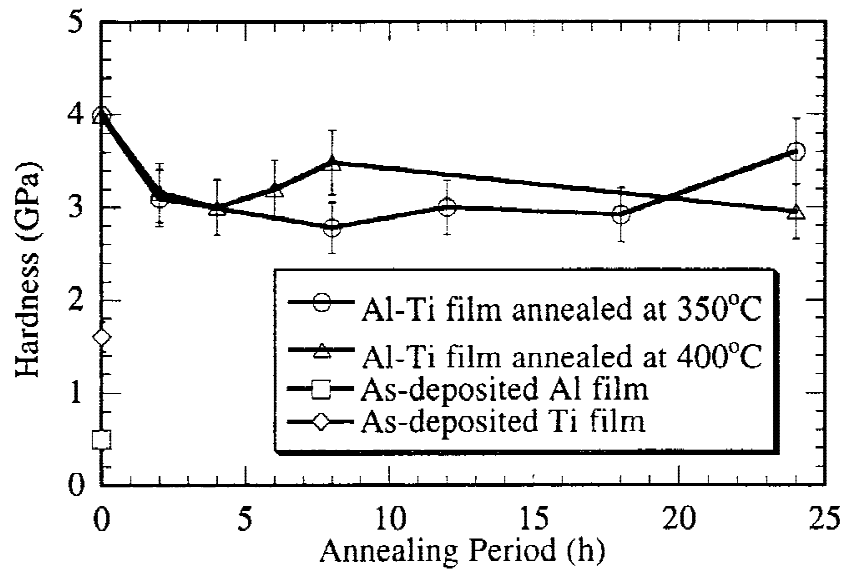

FIG. 13. Variation of nanoindentation hardness of Al-Ti multilayered film with increasing time of annealing at 350 and $400{ }^{\circ} \mathrm{C}$. The hardness values of sputter-deposited pure $\mathrm{Al}$ and $\mathrm{Ti}$ films are shown for comparison.

those of as-deposited pure $\mathrm{Al}$ and $\mathrm{Ti}$ films of similar thickness on Si substrates. The as-deposited 1.7- $\mu \mathrm{m}-$ thick Al-Ti film had a hardness of 4.0 GPa. On annealing at $350{ }^{\circ} \mathrm{C}$, the hardness dropped sharply to $3.1 \mathrm{GPa}$ after $2 \mathrm{~h}$ of annealing, and to the minimum value of $2.8 \mathrm{GPa}$ after $8 \mathrm{~h}$. Further annealing at $350^{\circ} \mathrm{C}$ showed a gradual increase in hardness, while there was a significant rise from 2.9 to $3.6 \mathrm{GPa}$ between 18 and $24 \mathrm{~h}$ of annealing time. On the other hand, during annealing at $400{ }^{\circ} \mathrm{C}$, the hardness of Al-Ti films decreased sharply to $3.16 \mathrm{GPa}$ after annealing for $2 \mathrm{~h}$ followed by a more gradual decrease to a minimum of $3.0 \mathrm{GPa}$ on annealing for $4 \mathrm{~h}$. On increase of annealing time to $8 \mathrm{~h}$, the hardness increased gradually to a maximum of $3.5 \mathrm{GPa}$, which was followed by a gradual decline to $2.95 \mathrm{GPa}$ on annealing for $24 \mathrm{~h}$. The high hardness in the as-deposited condition, almost a factor of 8 higher than that of pure $\mathrm{Al}$, can be due to the interlayer interfaces hindering dislocation motion in the Al-Ti layered structure. As the layered structure is degraded in the initial periods of annealing [Figs. 5(a)5(c)], the hardness values decrease. It should be noted that the drop in hardness after $2 \mathrm{~h}$ of annealing at $350{ }^{\circ} \mathrm{C}$ is independent of the fact that the residual stress did not show any change; hence the high hardness values in the as-deposited films are not due to stress in the films. Subsequently the hardness increased with an increase in volume fraction of $\mathrm{Al}_{3} \mathrm{Ti}$ precipitates. However it took a much longer period of annealing at $350{ }^{\circ} \mathrm{C}$, as compared to that at $400{ }^{\circ} \mathrm{C}$ for the hardness to show the increase after the initial sharp fall, because the diffusioncontrolled kinetics of the chemical reaction leading to the precipitation of $\mathrm{Al}_{3} \mathrm{Ti}$ dispersoids is slower at $350{ }^{\circ} \mathrm{C}$. As the $\mathrm{Al}$ grain and $\mathrm{Al}_{3} \mathrm{Ti}$ particle sizes do not alter much with an increase in time of annealing, the hardness variation is regulated by the progress of the chemical reaction between $\mathrm{Al}$ and $\mathrm{Ti}$ and the corresponding increase in the
$\mathrm{Al}_{3} \mathrm{Ti}$ volume fraction. Pure $\mathrm{Al}$ and $\mathrm{Ti}$ films have hardness values of 0.49 and $1.57 \mathrm{GPa}$, respectively. This implies a 6-fold increase in strength as compared to pure $\mathrm{Al}$, and a factor of two improvement over pure $\mathrm{Ti}$, in the $\mathrm{Al}-\mathrm{Al}_{3} \mathrm{Ti}$ composite. Further research is planned on free-standing Al-Ti films to study the mechanical behavior of bulk samples processed by magnetron sputtering. The results of the annealing experiments for the Al-Ti composition used in this study would be relevant for other compositions with lower Ti concentration also.

\section{CONCLUSIONS}

The following conclusions can be drawn from the present study:

(1) The as-deposited Al-Ti films show evidence of columnar growth. The $\mathrm{Al}$ (fcc)//Ti (hcp) interface is semicoherent.

(2) Annealing of the multilayered Al-Ti films at $350{ }^{\circ} \mathrm{C}\left(0.67 T_{\mathrm{m}}\right.$ of $\left.\mathrm{Al}\right)$ or $400{ }^{\circ} \mathrm{C}\left(0.72 T_{\mathrm{m}}\right.$ of $\left.\mathrm{Al}\right)$ leads to the degradation of the layered structure by interdiffusion between the layers and chemical reaction to precipitate $\mathrm{Al}_{3} \mathrm{Ti}$ phase. $\mathrm{Al}_{3} \mathrm{Ti}$ precipitates possibly have a metastable $\mathrm{L1}_{2}$ structure during nucleation, which changes to stable $\mathrm{DO}_{22}$ with increase in the time or temperature of annealing. With the progress of annealing, the layered structure is completely replaced by an $\mathrm{Al}-\mathrm{Al}_{3} \mathrm{Ti}$ dual phase microstructure with $\mathrm{Al}_{3} \mathrm{Ti}$ dispersed evenly and mostly at the $\mathrm{Al}$ grain boundaries.

(3) With increase in the time of annealing, the size distributions of $\mathrm{Al}$ grains and $\mathrm{Al}_{3} \mathrm{Ti}$ particles widen and the mean values of the distributions increase. The $\{111\}$ fiber texture observed in $\mathrm{Al}$ grains disappears on annealing the layered samples to obtain an equilibrium microstructure at 350 or $400{ }^{\circ} \mathrm{C}$ with randomly oriented $\mathrm{Al}$ grains.

(4) DTA studies have shown that the chemical reaction, $3 \mathrm{Al}+\mathrm{Ti} \rightarrow \mathrm{Al}_{3} \mathrm{Ti}$ takes place exothermically between 320 and $390{ }^{\circ} \mathrm{C}$, depending on the heating rate. The activation energy of the exothermic reaction has been found to be $106.5 \mathrm{kJK}^{-1} \mathrm{~mol}^{-1}$.

(5) The residual stress in Al-Ti multilayered films on $\mathrm{Si}$ substrate is tensile in the as-deposited condition. The stress was found to be same as that of as-deposited film after annealing at $350{ }^{\circ} \mathrm{C}$ for $2 \mathrm{~h}$, even if the layered structure is disrupted, which suggests that stress relief due to annealing is compensated for by increase in tensile stress component due to phase transformations and CTE mismatch between the film and the substrate. But the stress increases on annealing at $400{ }^{\circ} \mathrm{C}$ for $2 \mathrm{~h}$, implying the effect of $\mathrm{Al}_{3} \mathrm{Ti}$ precipitation and accompanying contraction in volume.

(6) The hardness measured using the nanoindenter shows a sharp decline after initial periods of annealing at 350 or $400{ }^{\circ} \mathrm{C}$, as the layered structure was continuously 
degraded. However with continued annealing, as the microstructure approaches an equilibrium state and the volume fraction of $\mathrm{Al}_{3} \mathrm{Ti}$ increases, the hardness increases back again. The hardness is 6 times higher than that of a pure $\mathrm{Al}$ film and a factor of two higher than that of a Ti film.

\section{ACKNOWLEDGMENTS}

The authors thank Ms. Julie Wessling of the Advanced Coating Technology Group for assistance with the deposition of the films. This research utilized the Materials Research Center Facilities at Northwestern University, supported by the National Science Foundation under Grant No. DMR-9632742. The authors appreciate the helpful comments and suggestions of the reviewers. One of the authors (R.M.) is grateful to the Defence Research and Development Organization, New Delhi, India for granting leave of absence for pursuing this research at Northwestern University.

\section{REFERENCES}

1. M.N. Rittner, J.R. Weertman, and J.A. Eastman, Acta Mater. 44, 1271 (1996).

2. S.R. Agnew, B.R. Elliot, C.J. Youngdahl, K.J. Hernker, and J.R. Weertman, in Modeling of Structure and Mechanics of Materials from Microscale to Product, edited by J.V. Carstensen, T. Leffers, T. Lorentzen, O.B. Pedersen, B.F. Sørensen and G. Winther (Ris $\varnothing$ National Laboratory, Roskilde, Denmark, 1998), p. 1.

3. E.G. Colgan, Mater. Sci. Rep. 5, 1 (1990).

4. F.J.J. Van Loo and G.D. Reick, Acta Metall. 21, 61 (1973).

5. M. Wittmer, F. Le Goues, and H-C. W. Huang, J. Electrochem. Soc. 132, 1450 (1985).

6. X.A. Zhao, F.C.T. So, and M-A. Nicolet, J. Appl. Phys. 63, 2800 (1998).

7. K.P. Mingard and B. Cantor, J. Mater. Res. 8, 274 (1993).

8. R.F. Lever, J.K. Howard, W.K. Chu, and P.J. Smith, J. Vac. Sci. Technol. 14, 158 (1977).

9. E.G. Colgan and J.W. Mayer, J. Mater. Res. 4, 815 (1989).

10. R. Banerjee, X.D. Zhang, S.A. Dregia, and H.L. Fraser, in Nanophase and Nanocomposite Materials II, edited by S. Komarreni, J.C. Parker, and H.J. Wollenberger (Mater. Res. Soc. Symp. Proc. 457, Pittsburgh, PA, 1997) p. 309.

11. P. Maugis, G. Blaise, and J. Philibert, in Interface Dynamics and Growth, edited by K.S. Liang, M.P. Anderson, R.F. Bruinsma, and G. Scoles (Mater. Res. Soc. Symp. Proc. 237, Pittsburgh, PA, 1992), p. 679.

12. R.W. Bower, Appl. Phys. Lett. 23, 99 (1973).

13. E.G. Colgan, M. Nastasi, and J.W. Mayer, J. Appl. Phys. 58, 4125 (1985).

14. M. Eizenberg, R.D. Thompson, and K.N. Tu, J. Appl. Phys. 53, 6891 (1982).

15. Q.Z. Hong, D.A. Lilientield, and J.W. Mayer, J. Appl. Phys. 64, 4478 (1988).
16. T. Matsui, K. Morii, and Y. Nakayama, Scripta Metall. Mater. 24, 1149 (1990).

17. E.G. Colgan and J.W. Mayer, J. Mater. Res. 4, 815 (1989).

18. J. Tardy and K.N. Tu, Phys. Rev. B 32, 2070 (1985).

19. E.G. Colgan and J.W. Mayer, Nucl. Inst. Methods B 17, 242 (1986).

20. C. Michaelsen, S. Wobhlert, R. Bormann, and K. Barmak, in Thermodynamics and Kinetics of Phase Transformations, edited by J.S. Im, B. Park, A.L. Greer, and G.B. Stephenson (Mater. Res. Symp. Proc. 398, Pittsburgh, PA, 1996), p. 245.

21. R. Mitra, A. Madan, R.A. Hoffman, W-A. Chiou, and J.R. Weertman, in Thin Films, Stresses and Mechanical Properties VIII, edited by R. Vinci, O. Kraft, N. Moody, P. Besser, and E. Shaffer II (Mater. Res. Soc. Symp. Proc. 594, Warrendale, PA), p. 43.

22. G.G. Stoney, Proc. Roy. Soc. London A82, 172 (1909).

23. W.C. Oliver and G.M. Pharr, J. Mater. Res. 7, 1564 (1992).

24. R. Ahuja and H.L. Fraser, JOM 46, 35 (1994).

25. R. Banerjee, S.A. Dregia, and H.L. Fraser, Acta Mater. 47, 4225 (1999).

26. R.A. Schwarzer, in Trends and New Applications of Thin Films, edited by H. Hoffman (Trans. Tech. Publications, UetikonZuerich, Switzerland, 1998).

27. R. Mitra, R.A. Hoffman, A. Madan, and J.R. Weertman, J. Mater. Res. 16, 1010 (2001).

28. R. Banerjee, R. Ahuja, and H.L. Fraser, Phys. Rev. Lett. 76, 3778 (1996).

29. J. Bonevich, D. van Heerden, and D. Josell, J. Mater. Res. 14, 1977 (1999).

30. D. van Hardeen, D. Josell, and D. Shectman, Acta Mater. 44, 297 (1996).

31. Powder Diffraction File, Card Nos. 4-787, 5-682, Inorganic Phases, JCPDS International Centre for Diffraction Data (Swarthmore, PA, 1989).

32. R. Banerjee, X-D. Zhang, S.A. Dregia, and H.L. Fraser, Acta Mater. 47, 1153 (1999).

33. S.A. Dregia, R. Banerjee, and H.L. Fraser, Scripta Mater. 39, 217 (1998).

34. I. Barin, Thermochemical Data of Pure Substances (VCH, Weinheim, Germany, 1989), p. 71.

35. R.W. Bené, Appl. Phys. Lett. 41, 529 (1982).

36. K-I. Ouchi, Y. lijima, and K-I. Hirano, in Titanium ' 80 Science and Technology, edited by H. Kimura and O. Izumi (Proc. 4th Int. Conf. Titanium, Kyoto, Japan, TMS, Warrendale, PA, 1980), p. 559.

37. E.B. Haugen, Probabilistic Approaches to Design (Wiley, New York, 1968), p. 47.

38. H.E. Kissinger, Analyt. Chem. 29, 1702 (1957).

39. H. Choi-Yim, R. Busch, U. Koster, and W.L. Johnson, Acta Mater. 47, 2455 (1999).

40. J.A. Ruud, A. Witvrouw, and F. Spaepen, J. Appl. Phys. 74, 2517 (1993).

41. A. Misra, H. Kung, T.E. Mitchell, and M. Nastasi, J. Mater. Res. 15, 756 (2000).

42. J.A. Bain, L.J. Chyung, S. Brennan, and B.M. Clemens, Phys. Rev. B 44, 1184 (1991).

43. R.C. Cammarata and K. Sieradzki, Phys. Rev. Lett. 62, 2005 (1989).

44. D.S. Gardner, T.L. Michalka, P.A. Flinn, T.W. Barbee, Jr., K.C. Saraswat, and J.D. Meindl, in Proc. 2nd Int. IEEE VLSI Multilevel Interconnection Conf, (IEEE, New York,1985), p.102. 